\title{
Geochemical constraints on basalt petrogenesis in the Strait of Sicily Rift Zone (Italy): Insights into the importance of short lengthscale mantle heterogeneity
} DOI:

10.1016/j.chemgeo.2020.119650

\section{Document Version \\ Accepted author manuscript}

Link to publication record in Manchester Research Explorer

Citation for published version (APA):

White, J. C., Neave, D. A., Rotolo, S. G., \& Parker, D. F. (2020). Geochemical constraints on basalt petrogenesis in the Strait of Sicily Rift Zone (Italy): Insights into the importance of short lengthscale mantle heterogeneity.

Chemical Geology, 119650. https://doi.org/10.1016/j.chemgeo.2020.119650

\section{Published in:}

Chemical Geology

\section{Citing this paper}

Please note that where the full-text provided on Manchester Research Explorer is the Author Accepted Manuscript or Proof version this may differ from the final Published version. If citing, it is advised that you check and use the publisher's definitive version.

\section{General rights}

Copyright and moral rights for the publications made accessible in the Research Explorer are retained by the authors and/or other copyright owners and it is a condition of accessing publications that users recognise and abide by the legal requirements associated with these rights.

\section{Takedown policy}

If you believe that this document breaches copyright please refer to the University of Manchester's Takedown Procedures [http://man.ac.uk/04Y6Bo] or contact uml.scholarlycommunications@manchester.ac.uk providing relevant details, so we can investigate your claim.

\section{OPEN ACCESS}


1

2

3

1 Geochemical constraints on basalt petrogenesis in the Strait of Sicily Rift Zone (Italy):

2 Insights into the importance of short lengthscale mantle heterogeneity.

3 Submitted to Chemical Geology

4 John Charles White ${ }^{1,{ }^{*}}$, David A. Neave ${ }^{2}$, Silvio G. Rotolo ${ }^{3,4}$, and Don F. Parker ${ }^{5, \dagger}$.

$5 \quad{ }^{1}$ Department of Geosciences

6 Eastern Kentucky University

7521 Lancaster Ave., Science 2234

8 Richmond, KY 40475 USA

9

$10 \quad{ }^{2}$ Department of Earth and Environmental Sciences

11 The University of Manchester

12 Oxford Road, Manchester

13 M13 9PL, UNITED KINGDOM

14

$15{ }^{3}$ Dipartimento di Scienze della Terra e del Mare (DiSTeM)

16 Università di Palermo

17 Via Archirafi 36

1890123 Palermo ITALY

19

$20{ }^{4}$ Instituto Nazionale di Geofisica e Vulcanologia (INGV)

21 Sezione di Palermo

22 Via Ugo La Malfa 153

2390146 Palermo ITALY

24

$25 \quad{ }^{5}$ Department of Geosciences

26 Baylor University

27 Waco, TX 76798 USA

*Corresponding author: john.white@eku.edu (e-mail), +1 859-622-1276 (phone), +1 859-622-

303357 (fax).

$32+$ Present address: School of Math and Science, Wayland Baptist University, 1900 West $7^{\text {th }}$

33 Street, Plainview, TX 79072 USA

34 


\section{Abstract}

36 Igneous activity from the late Miocene to historic time (most recently $1891 \mathrm{CE})$ in the Strait of

37 Sicily has created two volcanic islands (Pantelleria and Linosa) and several seamounts. These

38 volcanoes are dominated by transitional (ol+hy-normative) to alkaline (ne-normative) basaltic

39 lavas and scoriae; volcanic felsic rocks (peralkaline trachyte-rhyolite) crop out only on

40 Pantelleria. Although most likely erupted through continental crust, basalts demonstrate no

41 evidence of crustal contamination and are geochemically similar to oceanic island basalts (OIB).

42 Despite their isotopic similarities, there are considerable compositional differences with respect

43 to major and trace element geochemistry both between and within the two islands that are due to

44 short-length scale mantle heterogeneity beneath the region as well as variability in partial

45 melting and magma storage conditions. Published geophysical surveys suggest that lithospheric

46 thickness beneath both islands is $\sim 60 \mathrm{~km}$; this is consistent with the results of our geochemical

47 modelling $(59-60 \mathrm{~km})$, which also suggest mantle potential temperatures between $1415-1435^{\circ} \mathrm{C}$,

48 similar to those documented in other continental passive rifts. Trace element and isotopic data

49 reveal that the asthenosphere beneath the Strait of Sicily is heterogenous at both inter-island

$50(100 \mathrm{~s}$ of $\mathrm{km})$ and intra-island $(10 \mathrm{~s}$ of $\mathrm{km})$ scales. Although there is some compositional overlap

51 between the two major synthems at Linosa, in general the older magmas (Arena Bianca, $700 \mathrm{ka}$ )

52 formed as a result of $\sim 5 \%$ partial melting of a depleted MORB mantle (DMM) source enriched

53 with a relatively small amount of recycled MORB material, whereas the younger magmas

54 (Monte Bandiera, $530 \mathrm{ka}$ ) formed as a result of $\sim 2 \%$ partial melting of a similar mantle source.

55 Pantelleria magmas formed from a higher degree $(\sim 6 \%)$ of partial melting of a DMM source

56 with a relatively greater amount of recycled MORB material and possibly other components.

57 Geochemical modelling also suggests the older magmas on Linosa differentiated at a much 
58 shallower level $(\sim 8 \mathrm{~km})$ than the younger magmas ( $\sim 25 \mathrm{~km}$, at or below the base of the crust)

59 prior to eruption. Magmas stored in higher-level reservoirs were effectively homogenized and

60 preserve a narrower compositional range than magmas sourced from depth. Data for the

61 seamounts are scarce and compromised by significant seawater alteration; thus, these volcanic

62 centers cannot be modelled but based on comparative geochemistry with the islands are likely

63 the result of even smaller $(<2 \%)$ degrees of partial melting beneath thicker $(>60 \mathrm{~km})$ lithosphere.

64 Despite the geophysical similarities between the two islands in terms of lithospheric thickness

65 and crustal thinning, melt productivity has been greater at Pantelleria, producing a much larger

66 island and sustaining felsic magmatism, which we hypothesize may ultimately be entirely due to

67 the local occurrence of much more fusible mantle.

69 Keywords: Strait of Sicily Rift Zone, Continental-OIB, Alkali Basalt, Mantle Melting, Mantle 70 Heterogeneity

71

72 1. Introduction

73 The Mediterranean Sea between the island of Sicily and the Tunisian coast is the setting

74 for magmatism with an Oceanic Island Basalt (OIB)-like affinity that has produced two islands

75 (Pantelleria and Linosa) and several seamounts that occur subparallel to the faulted margins of

76 two of the three northwest-southeast trending grabens that comprise the Strait of Sicily Rift Zone

77 (SSRZ; Figure 1). Transitional (hy+ol-normative) to alkali (ne-normative) basaltic lavas and

78 tuffs occur throughout the SSRZ, with evolved lavas and tuffs (peralkaline trachyte and rhyolite

79 [pantellerite]) cropping out only at Pantelleria, where they form a bimodal association typical of 80 intraplate magmatic settings (Mahood and Hildreth, 1986; Civetta et al., 1998; Bindi et al., 2002; 
81 Rotolo et al., 2006; Di Bella et al., 2008; White et al., 2009; Neave et al., 2012; Avanzinelli et 82 al., 2014).

83 Geochemical studies have revealed that the mantle source for the SSRZ is almost 84 isotopically homogenous: basalts throughout the rift zone have nearly identical ${ }^{87} \mathrm{Sr} /{ }^{86} \mathrm{Sr}$ ratios 85 (Linosa: $0.7031 \pm 0.0001$; Pantelleria: $0.7032 \pm 0.0001$; Seamounts: $0.7035 \pm 0.0005)$ and very 86 similar ${ }^{143} \mathrm{Nd} /{ }^{144} \mathrm{Nd}$ ratios (Linosa: 0.51291-0.51297 [ $\left.\varepsilon_{\mathrm{Nd}}=5.9 \pm 0.5\right]$; Pantelleria: 0.51287$870.51299\left[\varepsilon_{\mathrm{Nd}}=6.3 \pm 0.5\right]$; Seamounts: $\left.0.51299-0.51312\left[\varepsilon_{\mathrm{Nd}}=7.7 \pm 0.5\right]\right)($ Esperança and Crisci, 88 1995; Civetta et al., 1998; Rotolo et al., 2006; Di Bella et al., 2008; Avanzinelli et al., 2014). 89 Helium isotopes recorded at both Pantelleria and Linosa are also similar $\left({ }^{3} \mathrm{He} /{ }^{4} \mathrm{He}=7.3-7.6\right.$ $90 \mathrm{R} / \mathrm{R}_{\mathrm{a}}$; Parello et al., 2000; Fouré et al., 2012) and MORB-like (8 $\pm 1 \mathrm{R} / \mathrm{R}_{\mathrm{a}}$; Class and Goldstein, 91 2005). Intra- and inter-island lead isotope ratio variations are larger, becoming more radiogenic 92 from the older Linosa suite (1070 to $\left.530 \mathrm{ka} ;{ }^{206} \mathrm{~Pb} /{ }^{204} \mathrm{~Pb}=19.320-19.540\right)$ to the paleo93 Pantelleria suite $\left(120-80 \mathrm{ka} ;{ }^{206} \mathrm{~Pb} /{ }^{204} \mathrm{~Pb}=19.664-19.981\right)$, with the younger (29-10 ka) neo94 Pantelleria suite showing intermediate values $\left({ }^{206} \mathrm{~Pb} /{ }^{204} \mathrm{~Pb}=19.445-19.791\right.$; Avanzinelli et al., 95 2014) and the Seamounts having a range that overlaps all of these $\left({ }^{206} \mathrm{~Pb} /{ }^{204} \mathrm{~Pb}=19.153-19.693\right.$; 96 Rotolo et al., 2006). These isotopic data place the Pantelleria and Linosa basalts on the Sr-Nd 97 mantle array between depleted MORB mantle (DMM) and primitive mantle (PM), where they 98 plot with OIB. On Sr-Nd-Pb diagrams they plot in the compositional space assigned to 99 "Prevalent Mantle" (PREMA) (Zindler and Hart, 1986; Stracke, 2012). These results have been 100 used to support diverse interpretations for the source origin of basaltic magmatism in the SSRZ: 101 (1) lithospheric mantle chemically modified by the addition of recycled MORB material 102 (Esperança and Crisci, 1995); (2) depleted MORB mantle enriched by a fossil plume of deep 103 mantle material (Civetta et al., 1998; Rotolo et al., 2006); (3) a mixture of asthenospheric and 
metasomatized lithospheric mantle (Di Bella et al., 2008); and (4) asthenosphere enriched with an eclogitic component representing recycled MORB material (Avanzinelli et al., 2014). In this latter study, Avanzinelli et al. (2014) included the results of U-series disequilibrium systematics for the neo-Pantelleria lavas and concluded that the sources for these are strictly asthenospheric with no need for interaction with lithospheric mantle or continental crust nor any need for a metasomatic component, thus ruling out hypotheses (1) and (3) listed above.

Unlike their isotopic ratios, the major and trace element geochemistry of the basalts demonstrates considerable variability. At Pantelleria, Civetta et al. (1998) divided the basalts into "High Ti-P" and "Low Ti-P" types, with the former also characterized by higher concentrations of incompatible trace elements and higher LREE/HREE than the latter, which they attributed to different degrees of partial melting from a locally heterogeneous asthenospheric mantle (cf. Mahood and Baker, 1986). Similar differences were described on Linosa, where Di Bella et al. (2008) recognized a "Trend-A" and "Trend-B", with the former having higher $\mathrm{K}_{2} \mathrm{O}, \mathrm{P}_{2} \mathrm{O}_{5}$, incompatible trace elements (e.g., Rb, Th), and LREE/HREE at a given MgO. Although Di Bella et al. (2008) attributed the differences between the volcanic centers of the SSRZ to varying degrees of partial melting from heterogeneous mantle sources, they modelled the Linosa trends as differentiates from a common primary magma (their hypothetical "Trend-C").

Several methods have been proposed to constrain mantle source compositions and partial melting parameters using major and trace element geochemistry. The first goal of this paper is to compare the results of some of these methods, including: (1) the use of olivine-liquid geothermobarometry to determine the average depth of partial melting and temperature of melt segregation from calculated primary basalts (Lee et al., 2009); (2) the use of major- and traceelement ratios to constrain mantle sources (e.g., Jackson and Dasgputa, 2008; Stracke and 
127 Bourdon, 2009; Dasgupta et al., 2010; Davis et al., 2013; Yang and Zhou, 2013); and (3) rare 128 earth element (REE) inverse models using the INVMEL algorithm to constrain mantle source 129 composition and the degree and depth range of partial melting (McKenzie and O’Nions, 1991, 130 1995). The second goal of this paper is to use the results of these various geochemical models 131 to: (1) determine the conditions of partial melting in the asthenosphere beneath the SSRZ; (2) 132 discriminate between the effects of lithospheric thickness, source lithology, and magma storage 133 on the geochemistry of these basalts; and (3) constrain the magma storage conditions in the crust 134 and describe its effect on basalt geochemistry.

\section{Geologic setting}

The SSRZ is a northwest-southeast trending transtensional rift system situated on the Pelagian Block, the northern promontory of the African plate that represents the foreland domain of the Apennine-Sicilian-Maghrebian orogen (Catalano et al., 2009; Martinelli et al., 2019). The SSRZ consists of three basins: the Pantelleria Trough, the Linosa Trough, and the Malta Trough.

141 Water depth is $<400 \mathrm{~m}$ beneath most of the Pelagian Block, increasing to $\sim 1350 \mathrm{~m}$ in the

142 Pantelleria Trough, $\sim 1580 \mathrm{~m}$ in the Linosa Trough, and $\sim 1720 \mathrm{~m}$ in the Malta Trough (Calanchi

143 et al., 1989; Civile et al., 2010). Volcanoes are present in or adjacent to all except the Malta 144 Trough, and include two islands (Pantelleria and Linosa) and several seamounts. The thickness 145 of the crust throughout most of the Pelagian Block is $25-35 \mathrm{~km}$, thinning to $16-18 \mathrm{~km}$ beneath 146 the troughs, 20-21 km beneath the island of Pantelleria, and 24-25 km beneath the island of 147 Linosa (Civile et al., 2008; Catalano et al., 2009). The depth to the lithosphere-asthenosphere 148 boundary has been inferred from regional geophysical studies. The Pelagian Block is 149 characterized by high heat flow $\left(>80 \mathrm{~mW} / \mathrm{m}^{2}\right)$ with values that increase to $>130 \mathrm{~mW} / \mathrm{m}^{2}$ in the 
Pantelleria and Linosa troughs (Della Vedova et al., 1995) and up to $200-460 \mathrm{~mW} / \mathrm{m}^{2}$ within the 151

Cinque Denti caldera (Bellani et al., 1995). Combined with positive Bouguer anomalies (65-103

mgal; Berrino and Capuano, 1995), several workers have suggested asthenospheric upwelling up to $\sim 60 \mathrm{~km}$ (Della Vedova et al., 1995; Argnani and Torelli, 2001; Civile et al., 2008).

Extension of the SSRZ began $\sim 7 \mathrm{Ma}$, with minor volcanism occurring during the late

155 Miocene (Messinian) and the vast majority of volcanism occurring during the Plio-Pleistocene

156 (Calanchi et al., 1989; Rotolo et al., 2006; Coltelli et al., 2016; Lodolo et al., 2019; Martinelli et

157 al., 2019). Volcanic seamounts are primarily located in one of three areas within the SSRZ

158 (Figure 1; Aissi et al., 2015): (1) the Graham and Terrible volcanic province (Anfirite, Tetide,

159 Galatea, Graham Bank, Cimotoe, Pinne, and Nameless Bank volcanoes), which lies 50-75 km

160 offshore and runs parallel to the coast of Sicily for $\sim 100 \mathrm{~km}$ between Mazara del Vallo and

161 Agrigento (Lodolo et al., 2019); (2) near the island of Pantelleria (Pantelleria SE, Pantelleria E,

162 Pantelleria SW, Pantelleria Central Bank, Angelia, and Foerstner volcanoes); and (3) north of the

163 island of Linosa (Linosa I, Linosa II, and Linosa III volcanoes). Within the Graham and Terrible

164 volcanic province, the oldest (late Miocene) is the Nameless Bank seamount, which lies $\sim 100 \mathrm{~km}$

165 east of Pantelleria and $\sim 70 \mathrm{~km}$ southwest of Agrigento and rises from a depth of 330-340 $\mathrm{m}$ to

$16680-90 \mathrm{~m}$ b.s.l.; the youngest is the Graham Bank seamount, which is located $\sim 50 \mathrm{~km}$ southwest

167 of Sciacca and $\sim 70 \mathrm{~km}$ northwest of Pantelleria, rises from 330-340 $\mathrm{m}$ to $7 \mathrm{~m}$ b.s.l., and last

168 erupted in $1831 \mathrm{CE}$ (producing the ephemeral "Ferdinandea Island"; Gemmellaro, 1831;

169 Washington, 1909; Kelly et al., 2014; Cavallaro and Coltelli, 2019.)

170 The island of Pantelleria is by far the larger $\left(83 \mathrm{~km}^{2}\right.$ surface area; $580 \mathrm{~km}^{2}$ total $)$ of the

171 two islands and represents the emergent portion of a volcanic edifice that rises $836 \mathrm{~m}$ above sea

172 level and $\sim 2200 \mathrm{~m}$ above the sea floor within the Pantelleria graben (Calanchi et al., 1989; Civile 
173 et al., 2010). Most rocks exposed on the island are felsic, volcanic (trachyte-pantellerite), and 174 younger than the $45.7 \pm 1.0 \mathrm{ka}$ pantelleritic Green Tuff, the caldera-forming ignimbrite of the 175 Cinque Denti caldera (Mahood and Hildreth, 1986; Scaillet et al., 2013). The oldest exposed 176 pantelleritic lava on the island has been dated at $324 \pm 11 \mathrm{ka}$ (Mahood and Hildreth, 1986), but 177 most of the island is submerged, much older, and most likely primarily basaltic (Fulignati et al., 178 1997). The oldest documented basalts ( 80-120 ka, herein termed "paleo-Pantelleria", following 179 Avanzinelli et al., 2004) are exposed primarily in outcrops along the coast and along the scarp of 180 the Cinque Denti caldera (Mahood and Hildreth, 1986). Younger mafic lavas ("neo-Pantelleria") 181 are found in the northwestern part of the island and include flows that erupted at $\sim 29$ ka from the 182 Cuddia Bruciata, Cuddia Ferle, and Cuddia del Monte cinder cones, and at $~ 10 \mathrm{ka}$ from the 183 Cuddie Rosse cinder cone (Mahood and Hildreth, 1986; Civetta et al., 1998). The most recent 184 volcanic activity occurred $\sim 4 \mathrm{~km} \mathrm{NW}$ of the island at the submarine (250 $\mathrm{m}$ b.s.1.) Foerstner 185 volcano on 17-25 October 1891 CE (Washington, 1909; Conte et al., 2014; Kelly et al., 2014). 186 The island of Linosa lies $\sim 120 \mathrm{~km}$ to the southeast of Pantelleria. Linosa is much smaller $187\left(5.4 \mathrm{~km}^{2}\right.$ surface area; $159 \mathrm{~km}^{2}$ total $)$ and represents the emergent portion of a large submarine 188 volcanic complex that rises $196 \mathrm{~m}$ above sea level and $\sim 800 \mathrm{~m}$ above the sea floor along the SW 189 edge of the Linosa graben (Rossi et al., 1996; Tonielli et al., 2019; Romagnoli et al., 2020). 190 Linosa is dominated by mafic lavas and tuffs that erupted in three stages at $1070 \mathrm{ka}$ (paleo191 Linosa), $700 \mathrm{ka}$ (Arena Bianca), and $530 \mathrm{ka}$ (Monte Bandiera) and created several coalescing 192 cinder cone and maar volcanoes (Lanzafame et al., 1994). The paleo-Linosa stage is 193 characterized primarily by hydromagmatic pyroclastic sequences with minor scoria and lava 194 which built maars and cinder cones. The beginning of the Arena Bianca stage was dominated by 195 hydromagmatism followed by eruptions of scoria that built the Monte Nero cinder cone and lava 
flows that created the eastern third of the present-day island. The Monte Bandiera stage also

began with hydromagmatic activity that created the Fossa Cappellano maar volcano (and associated Monte Bandiera tuff ring), which was followed by eruptions of scoria and lava that built the Montagna Rossa and Monte Vulcano cinder cones that dominate the western two-thirds of the island (Rossi et al., 1996).

\section{Methods and Results}

\subsection{Methods and materials}

Twenty-two samples of mafic lava and scoria were collected from the islands of Pantelleria (12) and Linosa (10) during field trips in 2003, 2006 and 2013, six of which were originally presented in Parker and White (2008) and White et al. (2009). These samples were powdered to -200 mesh in a pre-contaminated shatterbox grinder and were analyzed at Activation Laboratories, Ontario, for major-elements by ICP-OES and trace-elements (including a full suite of rare earth elements [REE]) by ICP-MS (Code 4Lithoresearch). Whole-rock analyses are presented in Table 1. For the discussion that follows, these analyses are combined with data from literature for a total of 134 analyses of mafic rocks $\left(\mathrm{SiO}_{2} \leq 52 \mathrm{wt} \%\right.$ normalized anhydrous); 75 of these include analyses of REE, including 39 from Pantelleria (Civetta et al., 1998; Esperança \& Crisci, 1995; Avanzinelli et al., 2004, 2014), 29 from Linosa (Bindi et al., 2002; Di Bella et al., 2008; Avanzinelli et al., 2014), and 7 from various Seamounts (Rotolo et al., 2006; with additional data from Beccaluva et al., 1981, and Calanchi et al., 1989). Excluded are the Khartibucale hawaiites at Pantelleria, which deserve a separate study; they have traceelement and isotopic signatures significantly different from the rest of the SSRZ mafic lavas and there are only three known published analyses, each of which is too evolved $(\mathrm{MgO}<5 \mathrm{wt} \%$, Ni 
$219<10 \mathrm{ppm}$ ) to be reliably used with the models presented in this study (Avanzinelli et al., 2004, 220 2014; White et al., 2009).

2213.2 Major-element geochemistry

222

223

22

225

226

227

228

229

230

231

232

233

234

235

236

237

238

239

240

241

All but five samples classify as either basalt or hawaiite (Figure 2a; Le Maitre, 2002), with basalts further classified based on normative mineralogy (assuming $\mathrm{FeO} / \mathrm{FeO} *=0.9$ ) as either alkali basalt (ol+ne-normative) or transitional basalt (ol+hy-normative) on their position in the basalt tetrahedron (Figure 2b; Irvine and Baragar, 1971). Linosa samples from the $1070 \mathrm{ka}$ paleo-Linosa and $530 \mathrm{ka}$ Monte Bandiera stages are dominated by alkali basalt, with the samples evolving from $\mathrm{Ol}^{\prime}$ (= normative ol $+0.25 \mathrm{hy}$ ) towards normative $\mathrm{Ab}$ along the $\mathrm{Ol}$ '-Ab join, which divides the "alkali" and "transitional" basalt fields. Linosa samples from the 700 ka Arena Bianca stage along with most Pantelleria samples classify predominantly as transitional basalts. Mafic lavas and scoriae from both trends are petrographically broadly similar, consisting of porphyritic rocks with variable amounts of phenocrysts of olivine, clinopyroxene, plagioclase, and magnetite (Rossi et al., 1996; Civetta et al., 1998; Bindi et al., 2002; Di Bella et al., 2008; and White et al., 2009 provide comprehensive descriptions).

Major-element variation diagrams that use $\mathrm{wt} \% \mathrm{MgO}$ as a differentiation index are plotted in Figure 3. Several differences can be seen between and within the Pantelleria and Linosa suites. Primitive basalts $(\mathrm{MgO}>9 \mathrm{wt} \%)$ have not been documented at Pantelleria (max $7.65 \mathrm{wt} \%$, median $5.82 \mathrm{wt} \% \mathrm{MgO})$, but have been at Linosa (max $16.35 \mathrm{wt} \%$, median $7.72 \mathrm{wt} \%$ $\mathrm{MgO})$. However, basalts with very high $(>14 \mathrm{wt} \%) \mathrm{MgO}$ at Linosa likely resulted from the accumulation of olivine (Di Bella et al., 2008). At a given concentration of $\mathrm{MgO}$, Linosa basalts have higher $\mathrm{SiO}_{2}$ and $\mathrm{Al}_{2} \mathrm{O}_{3}$, but lower $\mathrm{FeO}^{*}, \mathrm{TiO}_{2}$, and $\mathrm{CaO}$ than Pantelleria basalts (Figures 3a, b, c, d, e). Within the Linosa samples, $\mathrm{CaO}$ increases with decreasing to $\mathrm{MgO}$ to $\sim 8 \mathrm{wt} \%$ after 
242 which it decreases. Two distinct trends are observed in plots of $\mathrm{TiO}_{2}$ and $\mathrm{K}_{2} \mathrm{O}$ versus $\mathrm{MgO}$

243 (Figures 3b, g). The higher- $\mathrm{TiO}_{2}, \mathrm{~K}_{2} \mathrm{O}$, and $\mathrm{P}_{2} \mathrm{O}_{5}$ trend (labelled " $\mathrm{A}$ ", following Di Bella et al., 244 2008) includes most of the younger Monte Bandiera (MB) basalts from Linosa and some 245 samples from the older suites; The lower- $\mathrm{TiO}_{2}, \mathrm{~K}_{2} \mathrm{O}$, and $\mathrm{P}_{2} \mathrm{O}_{5}$ trend (labelled " $\mathrm{B}$ ", following Di 246 Bella et al., 2008) includes most of the older Arena Bianca (AB) basalts from Linosa and some 247 samples from both MB and the older Paleo-Linosa (PL) suites. The younger basalts from 248 Pantelleria (neo-Pantelleria; NP) form trends similar to Trend B with respect to $\mathrm{K}_{2} \mathrm{O}$ (but at 249 slightly lower values) and $\mathrm{P}_{2} \mathrm{O}_{5}$ but with considerably higher $\mathrm{TiO}_{2}$, whereas the older basalts 250 (paleo-Pantelleria; PP) define no coherent trend, and are characterized by even higher $\mathrm{TiO}_{2}(>3$ $251 \mathrm{wt} \%$ ) and $\mathrm{P}_{2} \mathrm{O}_{5}(>1 \mathrm{wt} \%$ ) than the NP basalts (Civetta et al., 1998). Bindi et al. (2002) and Di 252 Bella et al. (2008) attributed the origin of the two suites at Linosa as the result of fractional 253 crystallization from similar, hypothetical parental basalts at different pressures, with "Trend-A" 254 representing a younger suite that crystallized at higher pressures based on clinopyroxene crystal 255 chemistry. In contrast, Civetta et al. (1998) attributed the differences between the High Ti-P and 256 Low Ti-P suites of Pantelleria to variable degrees of partial melting from a heterogeneous mantle 257 source in addition to fractional crystallization.

$258 \quad 3.3$ Trace-element geochemistry

259 Trace-element variation diagrams that use $\mathrm{MgO}$ as a differentiation index are plotted in 
(HFSE: $\mathrm{Zr}, \mathrm{Nb}$ ) form distinct trends, similar to $\mathrm{K}_{2} \mathrm{O}$ and $\mathrm{TiO}_{2}$. Trend-A is again dominated by

the Monte Bandiera (MB) lavas from Linosa, and includes a few samples from the other Linosan

(

268 Arena Bianca (AB) lavas from Linosa as well as a few samples from the other Linosan suites as 269 well as most of the neo-Pantelleria (NP) samples and some of the PP samples. At a given value 270 of $\mathrm{MgO}$, the NP samples demonstrate slightly lower values of $\mathrm{Rb}, \mathrm{Zr}, \mathrm{Nb}$, and $\mathrm{La}$ than the $\mathrm{MB}$ 271 samples.

274 Panelleria (NP; Figure 5e) display the most constant values, with $\mathrm{La}_{\mathrm{N}} / \mathrm{Yb}_{\mathrm{N}}$ enrichments of $\sim 7.0$ 275 and 9.5 and $\mathrm{Sm}_{\mathrm{N}} / \mathrm{Yb}_{\mathrm{N}}$ enrichments of $\sim 2.7$ and 3.8, respectively. Monte Bandiera (MB; Figure 276 5c) has a large range of $\mathrm{La}_{\mathrm{N}} / \mathrm{Yb}_{\mathrm{N}}$ values, but near-constant $\mathrm{Sm}_{\mathrm{N}} / \mathrm{Yb}_{\mathrm{N}}$. Paleo-Linosa samples (PL; 277 Figure 5a) have similar HREE concentrations, but $\mathrm{La}_{N} / \mathrm{Yb}_{\mathrm{N}}$ values either more similar to $\mathrm{AB}$ or 278 MB. Paleo-Pantelleria (PP) and the seamounts (SEA) have the least internal consistency, at least 279 in part because unlike the others they represent discrete volcanic centers that erupted over $\sim 120$ $280 \mathrm{ka}$ and $8 \mathrm{Ma}$, respectively. Several PP samples have $\mathrm{La}_{\mathrm{N}} / \mathrm{Yb}_{\mathrm{N}}$ and $\mathrm{Sm}_{\mathrm{N}} / \mathrm{Yb}_{\mathrm{N}}$ ratios similar to NP. 281 Positive $\mathrm{Eu}$ anomalies (i.e., $\mathrm{Eu}_{\mathrm{N}} / \mathrm{Eu}^{*}>1.0$, with $\mathrm{Eu}^{*}=\left[\mathrm{Sm}_{\mathrm{N}} \cdot \mathrm{Gd}_{\mathrm{N}}\right]^{1 / 2}$ ) characterize basalts on 282 both islands, with Pantelleria basalts $\left(\mathrm{PP} \mathrm{Eu}_{\mathrm{N}} / \mathrm{Eu}^{*}=1.13 \pm 0.17 ; \mathrm{NP} \mathrm{Eu}_{\mathrm{N}} / \mathrm{Eu}^{*}=1.17 \pm 0.09\right)$ 283 having a more pronounced anomaly than Linosa basalts $\left(\mathrm{Eu}_{\mathrm{N}} / \mathrm{Eu}^{*}=1.06 \pm 0.07\right)$. Positive Eu 284 anomalies are a common feature in primitive $(\mathrm{MgO}>9 \mathrm{wt} \%) \mathrm{MORB}$ and $\mathrm{OIB}$ and have been 285 interpreted as evidence of mixing of DMM with recycled lower continental lithosphere (Niu and 286 O'Hara, 2009; Tang et al., 2015); however, the lack of a negative correlation between $\mathrm{Eu}_{\mathrm{N}} / \mathrm{Eu}^{*}$ 287 and radiogenetic lead isotope ratios makes lower continental crust an unlikely component. 
288 Likewise, the ubiquity of the positive Eu anomaly in SSRZ basalts coupled with its presence in 289 aphyric and low-phyric basalts, along with a lack of correlation between $\mathrm{Eu}_{\mathrm{N}} / \mathrm{Eu}^{*}$ and $\mathrm{Sr}$, 290 strongly suggests that plagioclase accumulation is an unlikely mechanism for producing this 291 anomaly in these rocks (Civetta et al., 1998; Bindi et al., 2002; Di Bella et al., 2008; White et al., 292 2009). Alternatively, a positive Eu anomaly may simply be due the relative incompatibility of 293 divalent Eu in clinopyroxene compared to trivalent Gd and Sm, coupled with more reducing 294 conditions in the source region which leads to higher $\mathrm{Eu}^{2+} / \mathrm{Eu}^{3+}$ and thus higher $\mathrm{Eu}_{\mathrm{N}} / \mathrm{Eu}^{*}$ in the 295 partial melts (Tang et al., 2017).

296

297 4.0 Discussion

298 4.1. Fractional crystallization and magma storage

299 Models of fractional crystallization/accumulation processes and magma storage 300 conditions are evaluated using Pearce (1968) element ratio (PER) diagrams coupled with the 301 results of thermodynamic (MELTS) modelling. PER diagrams plot ratios of major elements or 302 combinations of major elements with a common incompatible, or "conserved", element (e.g., $303 \mathrm{Mg} / \mathrm{K}$ vs. $\mathrm{Ca} / \mathrm{K}$ or $[\mathrm{Si}+\mathrm{Al}] / \mathrm{Zr}$ vs. $[\mathrm{Na}+\mathrm{K}] / \mathrm{Zr})$. Interpretations of these diagrams are based on the 304 stoichiometry of rock-forming minerals, and slopes of data distributions are equal to major 305 element ratios of minerals lost or gained during differentiation of a cogenetic suite of rocks 306 (Russell and Nicholls, 1988). For example, data plotted with $\mathrm{Mg} / \mathrm{K}$ on the abscissa and $\mathrm{Ca} / \mathrm{K}$ or $307 \mathrm{Al} / \mathrm{K}$ on the ordinate will form a linear trend with a slope that varies depending on the 308 fractionating or accumulating assemblage from horizontal for a phase with non-stoichiometric $309 \mathrm{Ca}$ or $\mathrm{Al}$ (e.g., olivine) to vertical for a phase with non-stoichiometric $\mathrm{Mg}$ (e.g., plagioclase). 310 Diagrams plotting $\mathrm{Mg} / \mathrm{K}$ versus $\mathrm{Al} / \mathrm{K}$ (Figure 6a) and $\mathrm{Ca} / \mathrm{K}$ (Figure $6 \mathrm{~b}$ ) can therefore be used to 
311 discriminate between fractionation or accumulation of olivine (horizontal slopes on both

312 diagrams with decreasing $\mathrm{Mg} / \mathrm{K}$ ), clinopyroxene (horizontal slope with $\mathrm{Al} / \mathrm{K}$ and a positive slope

313 with $\mathrm{Ca} / \mathrm{K}$ versus $\mathrm{Mg} / \mathrm{K}$ ), and plagioclase (positive slopes on both diagrams). The two Linosa

314 trends (hereafter LIN-A and LIN-B) observed in the major- and trace-element variation diagrams

315 (Figures 3 and 4) are also seen in the PER diagrams. These first preclude the possibility of a

316 common parental magma for the two trends; linking LIN-A and LIN-B by fractional

317 crystallization would require the crystallization of geologically implausible mineral assemblages.

318 PER diagrams suggest that LIN-A is formed by a paragenetic sequence of olivine to olivine +

319 clinopyroxene to clinopyroxene + plagioclase \pm olivine and LIN-B is formed by a continuous

320 sequence of plagioclase + clinopyroxene \pm olivine. Samples with $\mathrm{Mg} / \mathrm{K}>12$ correspond to

321 those with $\mathrm{MgO}>14 \mathrm{wt} \%$ and are most likely the result of olivine accumulation. Both trends

322 converge at $\mathrm{Mg} / \mathrm{K} \approx 4$, which corresponds to $\mathrm{MgO} \approx 6.5 \mathrm{wt} \%$. Pantelleria basalts form a trend

323 subparallel to LIN-B, suggesting that these magmas evolved along a similar liquid line of

324 descent.

325 These interpretations are in accord with the results of thermodynamic models of

326 fractional crystallization. Models were produced using the MELTS algorithm (rhyolite-MELTS

327 v. 1.0.2; Ghiorso and Sack, 1995; Asimow and Ghiorso, 1998; Gualda et al., 2012), the results of

328 which are superimposed on the data in Figure 6. The models presented were calculated under

329 anydrous conditions with oxygen fugacities fixed to the fayalite-magnetite-quartz (FMQ) buffer

330 and a step size of $5^{\circ} \mathrm{C}$. LIN-A is most successfully modeled as fractional crystallization from the

331 most primitive MB basalt (LSN51, 12.59 wt\% MgO, Mg\#=0.70, 278 ppm Ni; Di Bella et al.,

332 2008) at $0.65 \mathrm{GPa}$. At this pressure olivine is the liquidus phase at $1376^{\circ} \mathrm{C}$, and is replaced by

333 clinopyroxene at $1281^{\circ} \mathrm{C}\left(\mathrm{MgO}^{\text {liq }}=8.83 \mathrm{wt} \%, \mathrm{~F}=0.89\right)$, which is joined by plagioclase at 
$3341191^{\circ} \mathrm{C}\left(\mathrm{MgO}^{\text {liq }}=4.40 \mathrm{wt} \%, \mathrm{~F}=0.56\right)$. In contrast, LIN-B is best modelled as the result of 335 fractional crystallization from the most primitive $\mathrm{AB}$ basalt (LNS40, $7.68 \mathrm{wt} \% \mathrm{MgO}, \mathrm{Mg \#}=$ $3360.59,85 \mathrm{ppm} \mathrm{Ni}$; Bindi et al., 2002) at 0.2. At this pressure, olivine is the liquidus phase at $3371206^{\circ} \mathrm{C}$, and is closely joined by plagioclase at $1201^{\circ} \mathrm{C}\left(\mathrm{MgO}^{\text {liq }}=7.45 \mathrm{wt} \%, \mathrm{~F}=0.95\right)$, and 338 clinopyroxene at $1196^{\circ} \mathrm{C}\left(\mathrm{MgO}^{\mathrm{liq}}=7.26 \mathrm{wt} \%, \mathrm{~F}=0.89\right.$. These models are consistent with the 339 mass balance models discussed by Di Bella et al. (2008) and the conclusions of Bindi et al. 340 (2002), who used evidence from clinopyroxene crystal chemistry to suggest that the depth and 341 pressure of fractional crystallization at Linosa increased with time from $700 \mathrm{ka}(\mathrm{AB})$ to $530 \mathrm{ka}$ 342 (MB). Assuming average crustal density of $2700 \mathrm{~km}$, this places the magma reservoir at $\sim 7.6 \mathrm{~km}$ 343 for the largely older LIN-B suite and $\sim 24.6 \mathrm{~km}$ for the younger LIN-A suite; these values 344 correspond closely to the depths of the top of the crystalline basement $(\sim 8 \mathrm{~km})$ and the Moho 345 (24-25 km) beneath Linosa, respectively (Civile et al., 2008). Thermodynamic models for the 346 younger Pantelleria basalts (NP) reported by White et al. (2009) have results similar to LIN-B, 347 but require lower pressures $(0.10 \mathrm{GPa})$ and more hydrous conditions $\left(1.0-1.5 \mathrm{wt} \% \mathrm{H}_{2} \mathrm{O}\right)$ with 348 olivine on the liquidus at $1135 \pm 10^{\circ} \mathrm{C}$, followed by clinopyroxene at $1125 \pm 10^{\circ} \mathrm{C}$ and plagioclase 349 at $1085 \pm 10^{\circ} \mathrm{C}$.

3504.2 Primary magma compositions and constraints on pressure and temperature of melt 351 generation

352 An estimate of the composition of primary basalts is necessary to determine the 353 conditions of partial melting in the mantle, such as the temperature, pressure/depth of melt 354 segregation, and melt fraction produced. However, every basalt has undergone some degree of 355 fractionation and assimilation prior to eruption and even if assimilation is assumed to be 356 negligible, once the fractionating magma is multiply saturated it becomes very difficult to back- 
357 calculate the liquid line of decent (O’Hara, 1968). To do so, of course, first requires the 358 assumption that the rock sample is relatively unweathered and has undergone only olivine 359 fractionation; for this reason, we include only relatively primitive samples characterized by very 360 low $(<1 \mathrm{wt} \%)$ LOI, relatively high $(>10 \mathrm{wt} \%) \mathrm{MgO}$, and a lack of a negative Eu anomaly. We 361 also exclude those with very high $(>14 \mathrm{wt} \%) \mathrm{MgO}$, which could be the result of olivine 362 accumulation (Di Bella et al., 2008). The only samples that fit these criteria are those fall along 363 the olivine fractiontion trend for LIN-A in Figure 6 (discussed in section 4.1). Therefore most of 364 the remainder of the discussion will focus on the origin of the basalts of this sub-group, with 365 inferences made for the origin of the others by comparison.

The composition of the primary magma parental to a basaltic rock may be estimated by 367 iteratively "correcting" it for olivine fractionation until the recalculated basalt has an $\mathrm{Mg \#}$ that 368 has been experimentally determined to be in equilibrium with mantle peridotite (Lee et al., 369 2009). Calculated (anhydrous) primary basalts in equilibrium with peridotite with an olivine 370 composition of $\mathrm{Fo}_{90}$ and $\mathrm{Fe}^{3+} / \Sigma \mathrm{Fe}=0.13$ (estimated following Cottrell and Kelley, 2013) for all 371 samples that meet the criteria above $(n=17)$ are very similar, classifying as alkali basalts with $372 \mathrm{SiO}_{2}=46.08 \pm 0.16 \mathrm{wt} \%, \mathrm{TiO}_{2}=1.94 \pm 0.06 \mathrm{wt} \%, \mathrm{Al}_{2} \mathrm{O}_{3}=13.05 \pm 0.51 \mathrm{wt} \%, \mathrm{Fe}_{2} \mathrm{O}_{3}=1.41 \pm$ $3730.02 w^{t} \%, \mathrm{FeO}=9.55 \pm 0.16 \mathrm{wt} \%, \mathrm{MnO}=0.16 \pm 0.01, \mathrm{MgO}=15.18 \pm 0.27 \mathrm{wt} \%, \mathrm{CaO}=8.57 \pm$ $3740.42 \mathrm{wt} \%, \mathrm{Na}_{2} \mathrm{O}=2.60 \pm 0.24 \mathrm{wt} \%$, and $\mathrm{K}_{2} \mathrm{O}=1.19 \pm 0.08 \mathrm{wt} \%$ (Table 2). Primary basalts 375 calculated from starting basalt compositions with $1 \mathrm{wt} \% \mathrm{H}_{2} \mathrm{O}$ have compositions that differ by $376<1 \%$ from each of these values, with the obvious exception of $\mathrm{H}_{2} \mathrm{O}(0.90 \pm 0.01 \mathrm{wt} \%)$. The 377 olivine-liquid thermobarometer of Lee et al. (2009) provides a weighted average of the 378 temperature and pressure of polybaric melting for the calculated primary basalts of $1449 \pm 8^{\circ} \mathrm{C}$ 379 and $2.57 \pm 0.09 \mathrm{GPa}$ for anhydrous basalts and $1422 \pm 7^{\circ} \mathrm{C}$ and $2.50 \pm 0.07 \mathrm{GPa}$ for hydrous 
basalts; individual values reported in Table 2 are plotted in Figure 7 along with the anhydrous

and hydrous (116 ppm $\mathrm{H}_{2} \mathrm{O}$, following Salters and Stracke, 2004) peridotite solidus (Katz et al., 2003), the estimted limits of spinel and garnet stability (following Klemme and O'Neill, 2000), and the approximate lithosphere-asthenosphere boundary (60 km; Civile et al., 2008). The

384 calculated average pressures of segregation correspond to depths of $83.2 \pm 2.6 \mathrm{~km}$ (anhydrous) 385 and $81.1 \pm 2.2 \mathrm{~km}$ (hydrous) which places their origin within the garnet-spinel transition zone, consistent with the interpretation of previous workers (Mahood and Baker, 1986; Civetta et al., 1998; Di Bella et al., 2008; Avanzinelli et al., 2014). These results suggest a mantle potential temperature between $1415 \pm 7$ and $1435 \pm 8^{\circ} \mathrm{C}$, with calculated melt fractions of $0.019 \pm 0.011$ (anhydrous) to $0.027 \pm 0.009$ (hydrous) under those conditions (Langmuir et al., 1992; Putirka, 2005; Putirka et al., 2007; Supplementary Data 1). Also plotted in Figure 7 are the isentropic partial melting paths for both (a) anhydrous and (b) hydrous (116 ppm $\mathrm{H}_{2} \mathrm{O}$ ) average DMM (Salters and Stracke, 2004). These paths were calculated with the pMELTS algorithm (v.5.6.1; Ghiorso et al., 2002) from the intersections of the (a) dry lherzolite solidus (Katz et al., 2003) with the $1435^{\circ} \mathrm{C}$ adiabat $\left(3.32 \mathrm{GPa}\right.$ or $\sim 106 \mathrm{~km}, 1470^{\circ} \mathrm{C}$ ) and the (b) hydrous lherzolite solidus with the $1415^{\circ} \mathrm{C}$ adiabat $\left(3.62 \mathrm{GPa}\right.$ or $\left.\sim 116 \mathrm{~km}, 1452^{\circ} \mathrm{C}\right)$ to the base of the lithosphere (1.8 GPa, corresponding to $\sim 60 \mathrm{~km}$ ). Both melting models were calculated with oxygen fugacities fixed at the FMQ buffer and a step size of 50 bars $(\sim 155 \mathrm{~m})$ and both predict final melt fractions of 2.2$2.5 \%$, consistent with the value estimated from olivine-liquid thermobarometry. Model temperatures are higher than those determined for "ambient" $\mathrm{MORB}$ mantle $\left(\mathrm{T}_{\mathrm{P}} \approx 1350^{\circ} \mathrm{C}, 0.7\right.$ 1.7 GPa; Lee et al., 2009) and similar to those determined for extension-related intraplate volcanism. Examples can be found in the Basin and Range province where the continental lithosphere has been similarly thinned, such as Owens Valley (southeastern California, USA; 
$\sim 1425^{\circ} \mathrm{C}, 60-80 \mathrm{~km}$; Lee et al., 2009) and Snow Canyon (southwestern Utah, USA; $\sim 1422^{\circ} \mathrm{C}, 58$ km; Plank and Forsythe, 216).

Various tests have been proposed to determine the source material for basalts based on 406 their major-element content, but these provide equivocal results for Pantelleria and Linosa. The 407 calculated composition of primary magma for Linosa-A places it within the field of experimental 408 partial melts of peridotite (Dasgupta et al., 2010), although the PRIMELTS3 algorithm places it 409 in the field of partial melts of "pyroxenite" (Herzberg and Asimow, 2008). The Yang and Zhou 410 (2013) test for mantle source composition is also equivocal: the $\mathrm{FC} 3 \mathrm{MS}\left(\mathrm{wt} \% \mathrm{FeO}^{\mathrm{T}} / \mathrm{CaO}-\right.$ $\left.4113 \mathrm{MgO} / \mathrm{SiO}_{2}\right)$ value of the calculated primary basalts $(0.26 \pm 0.07)$ is within the range for both 412 peridotite $(-0.07 \pm 0.51)$ and pyroxenite $(0.46 \pm 0.96)$ partial melts. Other major-element ratios 413 purported to flag source compositions for basalts include $\mathrm{CaO} / \mathrm{Al}_{2} \mathrm{O}_{3}, \mathrm{~K}_{2} \mathrm{O} / \mathrm{TiO}_{2}$ (Jackson and 414 Dasgupta, 2008), and Fe/Mn (Davis et al., 2013) and provide similarly ambiguous results: $415 \mathrm{CaO} / \mathrm{Al}_{2} \mathrm{O}_{3}(0.65 \pm 0.05)$ and $\mathrm{K}_{2} \mathrm{O} / \mathrm{TiO}_{2}(0.61 \pm 0.04)$ plot nearest the $\mathrm{EM} 1$ component and 416 furthest from the MORB-HIMU array, inconsistent with isotopic evidence; and $\mathrm{Fe} / \mathrm{Mn}$ for all 417 basalts from both islands is $61.1 \pm 5.6$, which is at the proposed boundary (62) for peridotite- vs. 418 eclogitic-derived melts. Therefore, we suggest that although these tests provide inconclusive 419 results, they also suggest that that unenriched DMM alone is an unlikely source for LIN-A 420 magmas specifically or for SSRZ basalts in general. Relatively high concentrations of $\mathrm{TiO}_{2}$ in the basalts may also support this hypothesis, as 422 well as point to a greater role for eclogite in the source of Pantelleria basalts compared to Linosa. 423 Following Prytulak and Elliot (2007), calculated values of $\mathrm{Ti}_{8}$ (viz., the regressed value of $\mathrm{TiO}_{2}$ 424 at $8 \mathrm{wt} \% \mathrm{MgO}$ ) for SSRZ basalts are 1.9 (LIN-B), 2.3 (LIN-A), and 3.0 (PNL-L); these 425 correspond to minimum concentrations (for $\mathrm{F}=0.01$ to 0.10 ) of $\mathrm{TiO}_{2}$ in the mantle source of 
$426 \sim 0.2-0.3 \mathrm{wt} \%$ for Linosa and $\sim 0.3-0.5 \mathrm{wt} \%$ for Pantelleria compared to a range of $\sim 0.13 \mathrm{wt} \%$

427 (DMM; Salters and Stracke, 2004) to $0.20 \mathrm{wt} \%$ (PM; McDonough and Sun, 1995). Given an

428 average concentration of $1.3 \mathrm{wt} \% \mathrm{TiO}_{2}$ in MORB (Sun and McDonough, 1989), these

429 concentrations could be achieved by 5-15\% recycled MORB (as eclogite) mixed with DMM for

430 Linosa and $15-30 \%$ for Pantelleria. Additionally, the high concentrations of $\mathrm{P}_{2} \mathrm{O}_{5}$ that

431 accompany elevated $\mathrm{TiO}_{2}$ in the Pantelleria basalts may also indicate a higher presence of

432 eclogite in their mantle source (Haggerty et al., 1994).

4334.3 Trace element constraints on partial melting and mantle sources

434 The isotopic heterogeneity of the mantle is an acquired feature, but how it correlates with

435 lithological heterogeneity is much less certain (Zindler and Hart, 1986; Dasgupta et al., 2010;

436 Stracke, 2012). As noted in the Introduction, there is very little variability with respect to $\mathrm{Sr}$ and

$437 \mathrm{Nd}$ isotopes in the SSRZ basalts (with the exception of the seamounts, which have high LOI [3.7

$438 \pm 2.5 \mathrm{wt} \%]$ and therefore may have been strongly affected by seawater weathering; Rotolo et al.,

439 2006). Despite this apparent isotopic homogeneity with respect to Sr-Nd-He, the data clearly

440 show several significant differences with respect to major- and trace-element compositions (and

441 Pb isotopes; Avanzinelli et al., 2014) as well as some key similarities.

$442 \mathrm{~K} / \mathrm{Nb}$ and $\mathrm{Nb} / \mathrm{U}$ ratios for Pantelleria (214 \pm 38 and $49 \pm 18)$ and Linosa (229 \pm 22 and

$44346 \pm 6)$ basalts are similar to global values for OIB $(253 \pm 71$ and $47 \pm 10$; Hofmann et al., 1986;

444 Halliday et al., 1995; Arevalo et al., 2009) and, combined with Sr-Nd-Pb-O isotope systematics

445 and U-series disequilibrium, argue strongly against a significant role for crustal contamination or

446 assimilation in the origin of these basalts (Avanzinelli et al., 2014). Pantelleria and Linosa also

447 have similar incompatible trace element ratios for $\mathrm{Th} / \mathrm{U}(3.3 \pm 0.8$ and $3.2 \pm 1.6), \mathrm{U} / \mathrm{Pb}(0.59 \pm$

$448 \quad 0.08$ and $0.57 \pm 0.16), \mathrm{Lu} / \mathrm{Hf}(0.08 \pm 0.01$ and $0.07 \pm 0.01)$, and $\mathrm{Rb} / \mathrm{Sr}(0.04 \pm 0.01$ and $0.05 \pm$ 
0.01) which are characteristic of HIMU end-member OIBs (Willbold and Stracke, 2006).

Despite these similarities, there are several systematic differences in other trace element ratios both between and within the islands and seamounts.

Ratios of incompatible trace elements (with REE ratios normalized to CI chondrite; 453 McDonough and Sun, 1995) are presented in Figure 8. $\mathrm{La}_{\mathrm{N}} / \mathrm{Yb}_{\mathrm{N}}$ is plotted against ppm La in 454 Figure 8a and shows a clear positive slope, strongly suggesting that variable degrees of partial 455 melting are at least partially responsible for compositional variation in these magmas, with the 456 higher values representing smaller melt fractions (e.g., Mahood and Baker, 1986). A plot of $457 \mathrm{Sm}_{\mathrm{N}} / \mathrm{Yb}_{\mathrm{N}}$ versus $\mathrm{La}_{\mathrm{N}} / \mathrm{Yb}_{\mathrm{N}}$ (Figure $\left.8 \mathrm{~b}\right)$ reveals four sub-groups, which we term LIN-A 458 (corresponding to the Linosa Trend-A described above), LIN-B (Linosa Trend-B), PNL-L 459 (consisting of neo-Pantelleria and geochemically similar paleo-Pantelleria samples), and PNL-H 460 (which includes both the high-Ti and P paleo-Pantelleria and the Seamount samples). The lack 461 of collinearity between these sub-groups suggests that, although internal variation within them 462 may be attributed to varying degrees of partial melting or fractional crystallization, the 463 differences in $\mathrm{Sm}_{N} / \mathrm{Yb}_{\mathrm{N}}$ at a given value of $\mathrm{La}_{N} / \mathrm{Yb}_{\mathrm{N}}$ requires different mantle sources, with the 464 higher $\mathrm{Sm}_{\mathrm{N}} / \mathrm{Yb}_{\mathrm{N}}$ sub-groups sources being higher in garnet. $\mathrm{La}_{\mathrm{N}} / \mathrm{Sm}_{\mathrm{N}}$ is a sensitive indicator of 465 partial melting, and therefore its overall positive correlation with $\mathrm{La}_{\mathrm{N}} / \mathrm{Yb}_{\mathrm{N}}$ (Figure 8c) reinforces 466 variation both between and within the groups as attributable to variable melt fractions; however, 467 as with $\mathrm{Sm}_{\mathrm{N}} / \mathrm{Yb}_{\mathrm{N}}$, the different trends formed by the Linosa and Pantelleria groups strongly point 468 to compositionally different mantle source regions. This is also seen in a plot of Dy/Dy* versus $469 \mathrm{Dy}_{\mathrm{N}} / \mathrm{Yb}_{\mathrm{N}}($ Figure $8 \mathrm{~d})$, which reveals three subparallel trends. In this diagram, sub-suite trends 470 with higher $\mathrm{Dy}_{\mathrm{N}} / \mathrm{Yb}_{\mathrm{N}}$ also indicate a source more enriched in garnet, and the diagonal variability 471 within each trend can be attributed to differentiation (Davidson et al., 2013). The presence of 
472 eclogite in the PNL-L source region (and for most of the paleo-Pantelleria samples in PNL-H)

473 may be flagged by the decoupled behavior of $\mathrm{Sm}_{\mathrm{N}} / \mathrm{Yb}_{\mathrm{N}}$ and $\mathrm{Zr} / \mathrm{Yb}$ seen in Figure $8 \mathrm{e}$.

474 Experimental work has shown that $\mathrm{Zr}$ is much less incompatible and possibly compatible in 475 grossular-rich (eclogitic) garnet compared to pyrope-rich (peridotitic) garnet, whereas $\mathrm{D}_{\mathrm{Sm}} / \mathrm{D}_{\mathrm{Yb}}$ is 476 similar in both lithologies (van Westrenen et al., 2001; Pertermann et al., 2004; Stracke and 477 Bourdon, 2009). Avanzinelli et al. (2014) documented a negative correlation between ${ }^{206} \mathrm{~Pb} /{ }^{204} \mathrm{~Pb}$ 478 and $\mathrm{Rb} / \mathrm{La}$ within the SSRZ basalts and suggested that this ratio may be used as a tracer of 479 recycled MORB in the source region following Willbold and Stracke (2006), who demonstrated 480 that $(\mathrm{Rb}, \mathrm{Ba}, \mathrm{K}) / \mathrm{La}$ ratios are systematically lower in basalts sourced from HIMU-like mantle. 481 The negative correlation between $\mathrm{Sm}_{\mathrm{N}} / \mathrm{Yb}_{\mathrm{N}}$ and $\mathrm{Rb} / \mathrm{La}$ in these suites (Figure $8 \mathrm{f}$ ) coupled with 482 the observations above may therefore provide futher evidence for eclogite in the mantle source. 483 From these observations, we hypothesize: (1) LIN-A and LIN-B are not related by fractional 484 crystallization processes; (2) LIN-A and LIN-B have similar $\mathrm{Dy}_{\mathrm{N}} / \mathrm{Yb}_{\mathrm{N}}$ and therefore may have 485 similar mantle sources with respect to garnet, with LIN-B derived from a higher melt fraction; 486 (3) the PNL sub-groups cannot be related via fractional crystallization; and (4) PNL-L and PNL$487 \mathrm{H}$ are either derived from different mantle sources or their differences reflect different degrees of 488 partial melting, with the relatively lower-melt fraction PNL-H sub-suite preserving more of the 489 signal of the more fusible, recycled material (possibly as eclogite). Due to the scarcity of data 490 (isotope and REE data are only available for Graham Bank, Nameless Bank, and Pantelleria SE) 491 and the lack of unaltered samples, it is more difficult to draw conclusions for the origin of the 492 seamounts, but their very high $\mathrm{La} / \mathrm{Yb}$ ratios point to melt fractions lower than Linosa (i.e., $~ 1 \%$ ) 493 and the generally higher values of $\mathrm{Sm} / \mathrm{Yb}, \mathrm{TiO}_{2}$, and $\mathrm{P}_{2} \mathrm{O}_{5}$ for Graham Bank and Nameless Bank 
494 may be attributed to magma generation away from the rift grabbens and beneath thicker 495 lithosphere (cf. Niu et al., 2011).

Spider diagrams of representative analyses from each of the sub-groups ordered by

497 increasing compatibility in oceanic basalts (following Sun and McDonough, 1989) and

498 normalized to DMM (Salters and Stracke, 2004) are presented in Figure 9. These are plotted

499 with the results of $2 \%(F=0.02)$ non-modal fractional melting of depleted garnet peridotite (GD)

500 and spinel peridotite (SD) (see Supplementary Data 2 for details.) The model results for partial

501 melting of DMM form patterns very similar to those formed by all four sub-groups. Most

502 notably, all groups form trends that run subparallel to the model results with excellent fits for the

503 LREE and more compatible elements, consistent with a similar origin by small degrees of partial

504 melting of depleted peridotite in the spinel-garnet transition zone followed by fractional

505 crystallization. However, several notable anomalies require additional explanation: (1) in

506 addition to DMM, the source regions for all four groups require a source component enriched in

507 LILE; (2) a positive P anomaly is present in both PNL groups, and is especially prominent in the

508 PNL-H lavas; (3) PNL suites are characterized by relatively high Ti and low Zr; and (4) the

509 strong variability in PNL-H LILE contents and ratios strongly suggests that several different

510 components must be present in the source region for these diverse magmas which clearly must

511 not be related by either partial melting or fractional crystallization processes.

512 Therefore, we posit: (1) all magmas originate in the spinel-garnet transition zone from a

513 source region dominated by DMM peridotite (Civetta et al., 1998; Neave et al., 2012;

514 Avanzinelli et al., 2014); (2) first-order differences between Pantelleria and Linosa/Seamounts

515 are due to a greater amount of lithologically-enriched and possibly eclogitic material mixed with

516 peridotite in the former (cf. Avanzinelli et al., 2014); (3) differences between the Seamounts, 
517 LIN-A, and LIN-B are due to variable degrees of partial melting, with the Seamounts and

518 Linosa-B being derived from the lowest and highest degrees of partial melting respectively; (4)

519 compositional diversity within the paleo-Pantelleria suite must reflect the presence of additional

520 diverse components in the mantle source and indicate mantle heterogeneity at the inter-island

521 (10s of km) scale beneath Pantelleria (cf. Civetta et al., 1998); and (5) compositional

522 homogeneity in the LIN-B and PNL-L is probably due to homogenization in high-level magma

523 reservoirs (see Figure 6), which obfuscates the variability from partial melting seen in LIN-A

524 and heterogeneity observed in PNL-H (e.g., McGee and Smith, 2016). In most PNL-L samples

525 and some PNL-H samples there is also a positive $\mathrm{Ba}$ anomaly which may be the result of a small

526 amount of assimilation of high-Ba alkali feldspar cumulate rock at Pantelleria (White et al.,

527 2012; Wolff, 2017).

$528 \quad 4.4$ Trace element models of partial melting

529 Whole-rock REE concentrations, along with major- and selected trace-element

530 concentrations, were used to model the conditions of partial melting beneath Pantelleria and

531 Linosa by means of the INVMEL program (McKenzie and O’Nions, 1991, 1995, 1998) as

532 modified by White et al. (1992). This program inverts REE geochemical data to find the best-fit

533 relationship between melt fraction and depth utilizing the partitioning behavior of a full suite of

534 REE in mantle phases (Neave et al., 2012). It does this by running an initial forward non-modal

535 fractional melting model with trial parameters, predicting the weighted average composition of

536 the fractional melt, calculating the root-mean square (RMS) error between the predicted and

537 observed calculations, and then adjusting the melt depth and degree curve to iteratively minimize

538 the error. After the best-fit parameters producing the least misfit have been determined, a final

539 forward non-modal fractional melting model is run through the remaining major- and trace- 
540 element data to evaluate the robustness of fit. Results are considered acceptable if RMS $<1$ and 541 the melting curve is relatively smooth. The program also estimates the quantity of olivine and 542 clinopyroxene fractionation (F), and the final melt fraction is adjusted by multiplication by $1 /(1$ $543 \mathrm{~F})$. The mantle source is set with the $\varepsilon_{\mathrm{Nd}}$ parameter, which calculates a mixture of DMM $\left(\varepsilon_{\mathrm{Nd}}=\right.$ $544+10,0.815 \mathrm{ppm} \mathrm{Nd}$ ) and bulk silicate earth ("Primitive" Mantle, PM: $\varepsilon_{\mathrm{Nd}}=0,1.08 \mathrm{ppm} \mathrm{Nd}$ ) 545 (McKenzie and O'Nions, 1991, 1998). The latter component does not necessarily represent 546 primitive mantle or deep mantle plume material, but serves as a proxy for various enriched 547 components such as recycled oceanic lithosphere that are well-mixed with peridotite and whose 548 compositions are not well-constrained (Gibson and Geist, 2010). Model mineral proportions and 549 chemical composition of DMM and PM sources are from McKenzie and O’Nions (1991, 1995), 550 with the mineral-liquid trace element partition coefficients compiled by Gibson and Geist (2010) 551 (See Supplementary Data 2). Inversion models for the three subgroups that are plausibly cogenetic (LIN-A, LIN-B, 553 and PNL-L) are presented in Figure 10. Average $\varepsilon_{\mathrm{Nd}}$ values from Linosa (5.89) were used to set 554 the mantle source region for both LIN-A and LIN-B, which corresponds to a mix of 66\% DMM 555 and 34\% PM; the average $\varepsilon_{\mathrm{Nd}}$ for Pantelleria used in the models (6.33) was used to set the mantle 556 source region for PNL-L, which corresponds to a mix of 70\% DMM and 30\% PM. Models were 557 calculated with the garnet-spinel transition zone fixed at 73-93 km (based on a mantle potential 558 temperaure of $1435^{\circ} \mathrm{C}$; Klemme and O'Neill, 2000), while the top and bottom of the melting 559 column were allowed to vary. All models fit the observed REE data well and within $1 \sigma$ (Figures $56010 \mathrm{a}, \mathrm{b}, \mathrm{c})$ with the exception of Eu in the PNL-L model, which is slightly higher. In the forward 561 models (Figures 10d, e, f), the results also fit the observed major and trace element data well, 562 with a few notable exceptions: observed $\mathrm{Th}$ and $\mathrm{Nb}$ values are ubiquitously higher (68-83\% and 
53-73\% respectively) than model results for both islands, but within error, and observed $\mathrm{Sr}$ and $\mathrm{Zr}$ values are lower (50\% and $17-28 \%$ respectively) than model results for Linosa, but within $1 \sigma$ 565 and below that at Pantelleria. The models with the best fits have the tops of the melting columns 
586 more enriched in incompatible trace elements. Likewise, the predicted melting column extends

587 below the peridotite solidus to $126 \mathrm{~km}$ at $\mathrm{T}_{\mathrm{P}}=1435^{\circ} \mathrm{C}$, consistent with early melting of

588 pyroxenitic material, which is more fusible than peridotite and under these conditions would

589 begin melting between 115-130 km (Hirschmann and Stolper, 1996; Kogiso et al., 1998;

590 Pertermann and Hirschmann, 2003). The model for PNL-L also suggests a fraction of partial

591 melting similar to LIN-B $(\sim 5.5 \%)$. The INVMEL model was applied to Pantelleria basalts by

592 Neave et al. (2012), who reported similar results (melting across 100-60 km with the garnet-

593 spinel transition zone between $90-70 \mathrm{~km}$, corresponding to a mantle potential temperature of

$\left.594 \sim 1400^{\circ} \mathrm{C}\right)$ but with a much lower melt fraction $(\sim 1.7 \%)$. This lower value is likely due to the

595 inclusion of high-La/Yb PNL-H samples with the PNL-L basalts and their use of a primitive

596 mantle source in their model.

597

$598 \quad 5.0$ Summary

599 Geochemical modelling of basaltic magmatism supports previous geophysical models for

600 the structure of the lithosphere in the Strait of Sicily, suggesting the lithosphere-asthenosphere

601 boundary beneath the islands occurs at $\sim 60 \mathrm{~km}$, with the Moho beneath Linosa at $\sim 24-25 \mathrm{~km}$ and

602 high-level magma reservoirs occuring at the top of the crystalline basement between 4 and $8 \mathrm{~km}$.

603 Basalts on both islands fractionated in high-level chambers, although the more primitive magmas

604 erupted on Linosa fractionated from chambers emplaced at the Moho. The asthenosphere

605 underneath the SSRZ is characterized by mantle potential temperatures of $1415-1435^{\circ} \mathrm{C}$ and

606 consists of depleted MORB lherzolite well-mixed with recycled MORB lithosphere (as

607 eclogite/garnet pyroxenite), in agreement with Avanzinelli et al. (2014). For the most primitve

608 basalts on Linosa (termed LIN-A and primarily represented by the younger [530 ka] Monte 
Bandiera volcanics), there is good agreement between major-element models (FRACTIONATEPT3; Lee et al., 2009), thermodynamic models of isentropic mantle melting (pMELTS; Ghiorso

(6)

et al., 2002), and trace element inversion models (INVMEL; McKenzie and O’Nions, 1991, 1995). The models collectively suggest that these basalts are the result of $\sim 2 \%$ partial melting of a mantle source dominated by depleted MORB mantle (DMM) lithologically enriched with a 614 relatively small fraction of recycled MORB (as eclogite/garnet pyroxenite). The older, generally 615 more evolved basalts on Linosa (termed LIN-B and primarily represented by the older [700 ka] 616 Arena Bianca volcanics) formed from a higher degree of partial melting $(\sim 5 \%)$ of the same 617 mantle source. In comparison with Linosa, the geochemistry of the basalts on Pantelleria 618 provide evidence that they were sourced from DMM-dominated mantle lithologically enriched 619 with a much larger fraction of recycled MORB and possibly other components; evidence for this 620 includes higher $\mathrm{TiO}_{2}$ and $\mathrm{P}_{2} \mathrm{O}_{5}$ at a given $\mathrm{MgO}$ compared to Linosa, higher $\mathrm{Sm} / \mathrm{Yb}$ and $\mathrm{Dy} / \mathrm{Yb}$ at 621 a given $\mathrm{La} / \mathrm{Yb}$ coupled with a lower $\mathrm{Zr} / \mathrm{Yb}$, and higher $\mathrm{Rb} / \mathrm{La}$ coupled with higher ${ }^{206} \mathrm{~Pb} /{ }^{204} \mathrm{~Pb}$ 622 ratios (cf. Avanzineli et al., 2004). The results of INVMEL modelling also indicate that the 623 Pantelleria basalts cannot be derived from a peridotite-only source. We hypothesize that greater 624 melt productivity at Pantelleria and its ability to drive felsic magmatism compared to the 625 remainder of the SSRZ may simply be due to the presence of more fusible mantle beneath the 626 island, indicating mantle heterogeneity at a relatively short length-scale in the SSRZ.

\section{Acknowledgements}

629 The authors thank editor Catherine Chauvel and two anonymous reviewers for their helpful 630 reviews of this paper. Earlier versions of this manuscript were reviewed by Ray Macdonald, 631 Silvio Mollo, and an anonymous reviewer whose comments improved it greatly. JCW would 
also like to thank Mitchell May and Cassie Simpson for their assistance in the field and computer lab, respectively. This study was funded in part by a grant to JCW from the University Research Committee and the Rowlett Award from the Society of Foundation Professors at Eastern Kentucky University. DAN was supported by a Presidential Fellowship from the University of Manchester

648 Arevalo, R.Jr., McDonough, W.F., Luong, M., 2009. The K/U ratio of the silicate Earth:

\section{References}

Aissi, M., Flovere, M., Würtz, M., 2015. Seamounts and seamount-like structures of Sardinia Channel, Strait of Sicily, Ionian Sea, and Adriatic Sea. In: Würtz, M., Rovere, M. (Editors), Atlas of the Mediterranean Seamounts and Seamount-like Structures. International Union for Conservation of Nature (IUCN), Gland, Switzerland and Málaga, Spain, 187-225, doi: 10.2305/ICUN.CH.2015.07.en

Argnani, A., Torelli, L., 2001. The Pelagian Shelf and its graben system (Italy/Tunisia). In: Ziegler, P.A., Cavazza, W., Robertson, A.H.F. and Crasquin-Soleau, S. (Editors), PeriTethys Memoir 6: Peri-Tethyan Rift/Wrench Basins and Passive Margins. Mém. Mus. Natl. Hist. Nat. 186, 529-544.

Insights into mantle composition, structure, and thermal evolution. Earth Planet. Sci. Lett. 278, 361-369, doi: 1016/j.espl.2008.12.023.

Asimow, P.D., Ghiorso, M.S., 1998. Algorighmic modifications extending MELTS to calculated subsolidus phase relations. Amer. Miner. 83, 1127-1131, doi: 10.2138/am-1998-9-1022. 
Avanzinelli, R., Bindi, L., Menchetti, S., Conticelli, S., 2004. Crystallization and genesis of peralkaline magmas from Pantelleria Volcano, Italy: An integrated petrological and crystal-chemical study. Lithos 73, 41-69, doi: 10.1016/j.lithos.2013.10.008.

Avanzinelli, R., Braschi, E., Marchionni, S., Bindi, L., 2014. Mantle melting in within-plate continental settings: $\mathrm{Sr}-\mathrm{Nd}-\mathrm{Pb}$ and $\mathrm{U}$-series isotope constraints in alkali basalts from the Sicily Channel (Pantelleria and Linosa Islands, Southern Italy). Lithos 188, 113-129. doi: 10.1016/j.lithos.2013.008.

Beccaluva, L., Colantoni, P., Di Girolamo, P., Savelli, C., 1981. Upper-Miocene submarine volcanism in the Strait of Sicily (Banco senza Nome). Bull. Volcanol. 44, 573-581, doi: 10.1007/BF02600587.

Bellani, S., Calore, C., Grassi, S., Squarci, P., 1995. Thermal prospecting in Pantelleria island (Sicily Channel, Italy). World Geothermal Congress, Firenze 1995, 2, 767-770, doi: 10.13140/RG.2.1.1040.0165.

Berrino, G., Capuano, P., 1995. Gravity anomalies and structures at the island of Pantelleria. Acta Vulcanol. 7, 19-26.

Bindi, L., Tasselli, F., Olmi, F., Peccerillo, A., Menchetti, S., 2002. Crystal chemistry of clinopyroxenes from Linosa Volcano, Sicily Channel, Italy: implications for modelling the magmatic plumbing system. Mineral. Mag. 66, 953-968, doi: $10.1180 / 0026461026660070$.

Calanchi, N., Colantoni, P., Rossi, P.L., Saitta, M., Serri, G., 1989. The Strait of Sicily continental rift systems: Physiography and petrochemistry of the submarine volcanic centers. Marine Geol. 87, 55-83, doi: 10.1016/0025-3227(89)90145-X. 
Catalano, S., De Guidi, G., Lanzafame, G., Monaco, C., Tortorici, L., 2009. Late Quaternary deformation on the island of Pantelleria: New constraints for the recent tectonic evolution of the Sicily Channel Rift (southern Italy). J. Geodyn. 48, 75-82, doi: 10.1016/j.jog.2009.06.005.

679 Cavallaro, D., Coltelli, M., 2019. The Graham Volcanic Field offshore southwestern Sicily 680 (Italy) revealted by high-resolutioon seafloor mapping and ROV images. Front. Earth Sci. $681 \quad 7: 311$, doi: 10.3389/feart.2019.00311.

682 Civetta, L., D'Antonio, M., Orsi, G., Tilton, G.R., 1998. The geochemistry of volcanic rocks 683 from Pantelleria Island, Sicily Channel: Petrogenesis and characteristics of the mantle source region. J. Petrol. 39, 1453-1491, doi: 10.1093/petrology/39.8.1453.

Civile, D., Lodolo, E., Tortorici, L.Lanzafame, G., Brancolini, G., 2008. Relationships between magmatism and tectonics in a continental rift: The Pantelleira Island region (Sicily Channel, Italy). Marine Geol. 251, 32-46, doi: 10.1016/j.margeo.2008.01.009.

Class, C., Goldstein, S.L., 2005. Evolution of helium isotopes in the Earth's mantle. Nature 436, 1107-1112, doi: 10.1038/nature03930.

Coltelli, M., Cavallaro, D., D’Anna, G., D’Alessandro, A., Grassa, F., Mangano, G., Patanè, D., Gresta, S., 2016. Exploring the submarine Graham Bank in the Sicily Channel. Ann. Geophys. 59(2), S0208, doi: 10.4401/ag-6929.

Conte, A.M., Martorelli, E., Calarco, M., Sposato, A., Perinelli, C., Coltelli, M., Chiocci, F.L., 2014. The 1891 submarine erupton offshore Pantelleria Island (Sicily Channel, Italy): Identification of the vent and characterization of products and eruptive style. Geochem. Geophys. Geosyst. 15, 2555-2574, doi: 10.1002/2014GC005238. 
Cottrell, E., Kelley, K.A., 2013. Redox heterogeneity in Mid-Ocean Ridge Basalts as a function of mantle source. Science 340, 1314-1317, doi: 10.1126/science.1233299.

Dasgupta, R., Jackson, M.G., Lee, C.-T.A., 2010. Major element chemistry of ocean island basalts - Conditions of mantle melting and heterogeneity of mantle source. Earth Planet. Sci. Lett. 289, 377-392, doi: 10.1016/j.espl.2009.11.027.

Davidson, J., Turner, S., Plank, T., 2013. Dy/Dy*: Variations arising from mantle sources and petrogenetic processes. J. Petrol. 54, 525-537, doi: 10.1093/petrology/egs076.

Davis, F.A., Humayun, M., Hirschmann, M.M., Cooper, R.S., 2013. Experimentally determined mineral/melt partitioning of first-row transition elements (FRTE) during partial melting of peridotite at $3 \mathrm{GPa}$. Geochim. Cosmochim. Acta 104, 232-260, doi: 10.1016/j.gca.2012.11.009.

Della Vedova, B., Lucazeau, F., Pasquale, V., Pellis, G., Verdoya, M., 1995. Heat flow in the tectonic provinces crossed by the southern segment of the European Geotraverse. Tectonophysics 244, 57-74, doi: 10.106/0040-1951(94)00217-W.

Di Bella, M., Russo, S., Petrelli, M., Peccerillo, A., 2008. Origin and evolution of the Pleistocene magmatism of Linosa Island (Sicily Channel, Italy). Eur. J. Mineral. 20: 587-601, doi: 10.1127/0935-1221/2008/0020-1832.

Esperança, S., Crisci, G.M., 1995. The island of Pantelleria: A case for the development of DMM-HIMU isotopic compositions in a long-lived extensional setting. Earth Planet. Sci. Lett. 136, 167-182, doi: 10.1016/0012-821X(95)00178-F.

Fouré, E., Allard, P., Jean-Baptiste, P.,Cellura, D., Parello, F., 2012. ${ }^{3} \mathrm{He} /{ }^{4} \mathrm{He}$ ratio in olivines from Linosa, Ustica, and Pantelleria Islands (Southern Italy). J. Geol. Res., doi: $10.1155 / 2012 / 723839$. 
720 Fulignati, P., Malfitano, G., Sbrana, A., 1997. The Pantelleria caldera geothermal system: Data from the hydrothermal minerals. J. Volcanol. Geotherm. Res. 75, 251-270, doi: 10.1016/S0377-0273(96)00066-2.

Gemmellaro, C., 1831. Relazione dei fenomeni del nuovo vulcano sorto dal mare fra la costa di Sicilia e l'isola di Pantelleria nel mese di luglio 1831. Atti dell'Accademia Gioenia di Scienze Naturali in Catania 8, 271-298.

Ghiorso, M.S., Sack, R.O., 1995. Chemical mass transfer in magmatic processes. IV. A revised and internally consistent thermodynamic model fo rthe interpolation and extraplation of liquid-solid equilibria in magmatic systems at elevated temperatures and pressures. Contrib. Mineral. Petrol. 119, 197-212, doi: 10.1007/BF00307281.

Ghiorso, M.S., Hirschmann, M.M., Reiners, P.W., Kress, V.C., 2002. The pMELTS: A revison of MELTS aimed at improving calculation of phase relations and major element partitioning involved in partial melting of the mantle at pressures up to $3 \mathrm{Gpa}$. Geochem. Geophys. 3(5), doi: 10.1029/2001GC000217.

Gibson, S.A., Geist, D., 2010. Geochemical and geophysical estimates of lithospheric thickness variation beheath Galápagos. Earth Planet. Sci. Lett. 300, 275-286, doi: 10.1016/j.eps1.2010.10.002.

Gualda, G.A.R., Ghiorso, M.S., Lemons, R.V., Carley, T.L., 2012. Rhyolite-MELTS: a modified calibration of MELTS optimized for silica-rich, fluid-bearing magmatic systems. J. Petrol. 53, 875-890, doi: 10.1093/petrology/egr080.

740 Haggerty, S.E., Fung, A.T., Burt, D.M., 1994. Apatite, phosphorous and titanium in eclogitic 741 garnet from the upper mantle. Geophys. Res. Lett. 21, 1699-1702, doi:

$742 \quad 10.1029 / 94 G L 01001$. 
Halliday, A.N., Lee, D.-C., Tommasini, S., Davies, G.R., Paslick, C.R., Fitton, J.G., James, D.E., 1995. Incompatible trace elements in OIB and MORB and source enrichment in the suboceanic mangle. Earth Planet. Sci. Lett. 113, 379-395, doi: 10.1016/0012821X(95)00097-V.

Herzberg, C., Asimow, P.D., 2008. PRIMELT3 MEGA.XLSM software for primary magma calculation: Peridotite primary magma $\mathrm{MgO}$ contents from the liquidus to the solidus. Geochem. Geophys. 16, 563-578, doi: 10.1002/2014GC00563.

Hirschmann, M.M., Stolper, E.M., 1996. A possible role for garnet pyroxenite in the origin of the "garnet signature" in MORB. Contrib. Mineral. Petrol. 124, 185-208, doi: $10.1007 / \mathrm{s} 004100050184$.

Hofmann, A.W., Jochum, K.P., Seufert, M., White, W.M., 1986. Nb and Pb in oceanic basalts: new constraints on mantle evolution. Earth Planet. Sci. Lett. 79, 33-45, doi: $10.1016 / 0012-821 X(86) 90038-5$.

Irvine, T.N., Baragar, W.R.A., 1971. A guide to the chemical classification of the common volcanic rocks. Can. J. Earth Sci. 8, 523-548, doi: 10.1139/e71-055.

Jackson, M.G., Dasgupta, R., 2008. Compositions of HIMU, EM1, and EM2 from global trends between radiogenic isotopes and major elements in oceanic island basalts. Earth Planet. Sci. Lett. 276, 175-186, doi: 10.1016/j.espl.2008.09.023.

Katz, R.F., Spiegelman, M., Langmuir, C.H., 2003. A new parameterization of hydrous manlte melting. Geochem. Geophys. 4(9), 1073, doi: 10.1029/2002GC000433.

Kelly, J.T., Carey, S., Pistolesi, M.., Rosi, M., Croff-Bell, K.L., Roman, C., Marani, M., 2014. Exploration o the 1891 Foerstner submarine vent site (Pantelleria, Italy): insights into the formation of basaltic balloons. Bull. Volc. 76:844, doi: 10.1007/s00445-014-0844-4. 
Klemme, S., O'Neill, H.StC., 2000. The near-solidus transition from garnet lherzolite to spinel lherzolite. Contrib. Mineral. Petrol. 138, 237-248, doi: 10.1007/s004100050560.

Kogiso, T., Hirose, K., Takahashi, E., 1998. Melting experiments on homogenous mixtures of peridotitee and basalt: application to the genesis of ocean island basalts. Earth Planet. Sci. Lett. 162, 45-61, doi: 10.1016/S0012-821X(98)00156-3.

Langmuir, C.H., Klein, E.M., Plank, T., 1992. Petrological systematics of mid-ocean ridge basalts: Constraints on melt generation beneath ocean ridges, In: J.P. Morgan, D.K. Blackman, and J.M. Sinton (Eds.) Mantle flow and melt generation at mid-ocean ridges, Geophys. Monogr. Ser. 71, 183-280. AGU, Washington D.C, doi: 10.1029/GM071p0183.

Lanzafame, G., Rossi, P.L., Tranne, C.A., Lanti, E., 1994. Carta geologica dell'isola di Linosa. 1:5000. Società Elaborazioni Cartografiche, Firenze.

Lee, C.-T.A., Luffi, P., Plank, T., Dalton, H., Leeman, W.P., 2009. Constraints on the depths and temperatures of basaltic magma generation on Earth and other terrestrial planets using new thermobarometers for mafic magmas. Earth Planet. Sci. Lett. 279, 20-33, doi: 10.1016/j.espl.2008.12.020.

Le Maitre, R.W. (Editor), 2002. Igneous rocks, a classification and glossary of terms: Recommendations of the International Union of Geological Sciences Subcomission on the Systematics of Igneous Rocks, $2^{\text {nd }}$ Ed. Cambridge University Press, 236 p.

Lodolo, E., Zampa, L., Civile, D., 2019. The Graham and Terrible volcanic province (NW Sicilian Channel): gravimetric constraints for the magmatic manifestations. Bull. Volcanol. 81, 17, doi:10.1007/s00445-019-1274-0. 
Mahood, G.A., Baker, D.R., 1986. Experimental constraints on depths of fractionation of mildly alkalic basalts and associated felsic rocks: Pantelleria, Strait of Sicily. Contrib. Mineral. Petrol. 93, 251-264, doi: 10.1007/BF00371327.

Mahood, G.A., Hildreth, W., 1986. Geology of the peralkaline volcano at Pantelleria, Strait of Sicily. Bull. Volcanol. 48, 143-172, doi: 10.1007/BF01046548.

Martinelli, M., Bistacchi, A., Balsamo, F., Meda, M., 2019. Late Oligocene to Pliocene extension in the Maltese islands and implications for geodynamics of the Pantelleria Rift and Pelagian Platform. Tectonics 38, 3394-3415, doi: 10.1029/2019TC005627.

McDonough, W.F., Sun, S.-s., 1995. The composition of the Earth. Chem. Geol. 120, 223-253.

McGee, L.E., Smith, I.E.M., Interpreting chemical compositions of small scale basaltic systems: A review. J. Volcanol. Geotherm. Res. 325, 45-60, doi: 10.1016/j.volgeores.2016.06.007.

McKenzie, D., Bickle, M.J., 1988. The volume and composition of melt generated by extension of the lithosphere. J. Petrol. 29, 625-679, doi: 10.1093/petrology/29.3.625.

McKenzie, D., O’Nions, R.K., 1991. Partial melt distributions from inverstion of rare earth element concentrations. J. Petrol. 32, 1021-1091, doi: 10.1093/petrology/32.5.1021.

McKenzie, D., O’Nions, R.K., 1995. The source regions of ocean island basalts. J. Petrol. 36, 133-159, doi: 10.1093/petrology/36.1.133.

806 McKenzie, D., O’Nions, R.K., 1998. Melt production beneath oceanic islands. Phys. Earth 807 Planet. Inter. 107, 143-182, doi: 10.1016/S0031-9201(97)00132-5.

808 Niu, Y., O'Hara, M.J., 2009. MORB mantle hosts the missing Eu (Sr, Nb, Ta, and Ti) in the 809 continental crust: New perspectives on crustal growth, crust-mantle differentiation and 

816

chemical signature of the oceanic upper mantle. Lithos 112, 1-17, doi: 10.1016/j.lithos.2008.12.009.

Niu, Y., Wilson, M., Humphrey, E.R., and O'Hara, M.J., 2011. The origin of intra-plate ocean island basalts (OIB): the lid effect and its geodynamic implications. J. Petrol. 52, 14431468, doi: 10.1093/petrology/egr030.

815 Neave, D.A., Fabbro, G., Herd, R.A., Petrone, C.M., Edmonds, M., 2012. Melting, differentiation and degassing at the Pantelleria Volcano, Italy. J. Petrol. 53, 637-663, doi: 10.1093/petrology/egr074.

O'Hara, M.J., 1968. The bearing of phase equilibria studies in synthetic and natural systems on the origin and evolution of basic and ultrabasic rocks. Earth. Sci. Rev. 4, 69-133, doi: 10.1016/0012-8252(68)90147-5..

Parello, F., Allard, P., D’Alessandro, W., Federico, C., Jean-Baptiste, P., Catani, O., 2000. Isotope geochemistry of Pantelleria volcanic fluids, Sicily Channel rift: a mantle volatile end-member for volcanism in southern Europe. Earth Planet. Sci. Lett. 180, 325-339, doi: $10.1016 / \mathrm{S} 0012-821 \mathrm{X}(00) 00183-7$.

Parker, D.F., White, J.C., 2008. Large-scale alkalic magmatism associated with the Buckhorn caldera, Trans-Pecos Texas, USA: Comparison with Pantelleria, Italy. Bull. Volcanol. 70, 403-415, doi: 10.1007/s00445-007-0145-2.

Pearce, T.H., 1968. A contribution to the theory of variation diagrams. Contrib. Mineral. Petrol. 19, 142-157, doi: 10.1007/BF00635485.

Pertermann, M., Hirschmann, M.M., 2003. Partial melting experiments on a MORB-like pyroxenite between 2 and $3 \mathrm{GPa}$ : Constraints on the presence of pyroxenite in basalt 
source retions from solidus location and melting rate. J. Geophys. Res. 108, no. B2, 2125, doi: 10.1029/2000JB000118.

Pertermann, M., Hirschmann, M.M., Hametner, K, Günther, D., Schmidt, M.W., 2004.

Experimental determination of trace element partitioning between garnet and silica-rich liquid during anhydrous melting of MORB-like eclogite. Geochem. Geophys. 5(5), Q05A01, doi: 10.1029/2003/GC000638.

Plank, T., Forsyth, D.W., 2016. Thermal structure and melting conditions in the mantle beneah the Basin and Range province from seismology and petrology. Geochem. Geophys. 17, 1312-1338, doi: 10.1002/2015GC006205.

Prytulak, J., Elliot, T., 2007. $\mathrm{TiO}_{2}$ enrichment in ocean island basalts. Earth Planet. Sci. Lett. 263, 388-403, doi: 10.1016/j.eps1.2007.09.015.

Putirka, K.D., 2005. Mantle potential temperatures at Hawaii, Iceland, and the mid-ocean ridge system, as inferred from olivine phenocrysts: Evidence for thermally driven mantle plumes. Geochem. Geophys. 6(5), Q05L08, doi: 10.1029/2005GC000915.

Putirka, K.D., Perfit, M., Ryerson, F.J., Jackson, M.G., 2007. Ambient and excess mantle termperatures, olivine thermometry, and active vs. passive upwelling. Chem. Geol. 241, 177-206, doi: 10.1016/j.chemgeo.2007.01.014.

Romagnoli, C., Belvisi, V., Innangi, S., Di Martino, G., Tonielli, R., 2020. New insights on the evolution of the Linosa volcano (Sicily Channel) from the study of its submarine portions. Mar. Geol. 419: 106060, doi: 10.1016/j.margeo.2019.106060.

Rossi, P.L., Tranne, C.A., Calanchi, N., Lanti, E., 1996. Geology, stratigraphy and volcanological evolution of the island of Linosa (Sicily Channel). Acta Vulcanol. 8, 7390. 

867 868 875 876

Rotolo, S.G., Castorina, F., Cellura, D., Pompilio, M., 2006. Petrology and geochemistry of submarine volcanism in the Sicily Channel rift. J. Geol. 114, 355-365, doi: $10.1086 / 501223$.

Russell, J.K., Nicholls, J., 1988. Analysis of petrologic hypotheses with Pearce element ratios. Contrib. Mineral. Petrol. 99, 25-35, doi: 10.1007/BF00399362.

Salters, V.J.M., Stracke, A., 2004. Composition of depleted mantle. Geochem. Geophys. 5(5), Q05004, doi:10.1029/2003GC000597.

Scaillet, S., Vita-Scaillet, G., Rotolo, S.G., 2013. Millennial-scale phase relationships between ice-core and Mediterranean marine records: insights from high-precision ${ }^{40} \mathrm{Ar}{ }^{39} \mathrm{Ar}$ dating of the Green Tuff of Pantelleria, Sicily Strait. Quat. Sci. Rev. 78, 141-154, doi: 10.1016/j.quascirev.2013.08.008.

Stracke, A., Bourdon, B., 2009. The importance of melt extraction for tracing mantle

871 Sun, S.-s., McDonough,W.F., 1989. Chemical and isotopic systematics of oceanic basalts:

874 Tang, M., Rudnick, R.L., McDonough, W.F., Gaschnig, R.M., Huang, Y., 2015. Europium heterogeneity. Geochim. Cosmochim. Acta 73, 218-238, doi: 10.1016/j.gca.2008.10.015.

Stracke, A., 2012. Earth's homegenous mantle: A product of convection-driven interacton between crust and mantle. Chem. Geol. 330-331, 274-299, doi: 10.1016/j.chemgeo.2012.08.007. implications for mantle composition and processes. Geol. Soc. Spec. Pub. 42, 313-345, doi: 10.1144/GSL.SP.1989.042.01.19. anomalies constrain the mass of recycled lower continental crust. Geology 43, 703-706, doi: $10.1130 / \mathrm{G} 36641.1$. 
Tang, M., McDonough, W.F., Ash, R.D., 2017. Europium and strontium anomalies in the MORB source mantle. Geochim. Cosmochim. Acta 197, 132-141, doi: 10.1016/j.gca.2016.10.025.

Tonielli, R., Innangi, S., Di Martino, G., Romagoli, C., 2019. New bathymetry of the Linosa volcanic complex from multibeam systems (Sicily Channel, Mediterranean Sea). J. Maps 15, 611-618, doi: 10.1080/17445647.2019.1642807.

van Westrenen, W., Blundy, J.D., Wood, B.J., 2001. High field strength element / rare earth element fractionation during partial melting in the presence of garnet: Implications for identification of mantle heterogeneities. Geochem. Geophys. 2(7), doi: 10.1029/2000GC000133.

Washington, H.S., 1909. Art. VIII.-The submarine eruptions of 1831 and 1891 near Pantelleria. Amer. J. Sci. 27(158), 131-150, doi: 10.2475/ajs.s4-27.158.131.

White, R.S., McKenzie, D., O’Nions, R.K., 1992. Oceanic crustal thickness from seismic measurements and rare earth element inversions. J. Geophys. Res. 97, 19683-19715, doi: 10.1029/92JB01749.

White, J.C., Parker, D.F., Ren, M., 2009. The origin of trachyte and pantellerite from Pantelleria, Italy: Insights from major element, trace element, and thermodynamic modelling. J. Volcanol. Geotherm. Res. 179, 33-55, doi: 10.1016/j.volgeores.2008.10.007.

White, J.C., Espejel-García, V.V., Anthony, E.Y., Omenda, P., 2012. Open system evolution of peralkaline trachyte and phonolite from the Suswa volcano, Kenya rift. Lithos 152, 84104, doi: 10.1016/j.lithos.2012.01.023.

Wolff, J.A., 2017. On the syenite-trachyte problem. Geology 45, 1067-1070, doi: 10.1130/G39415.1. 
900 Willbold, M., Stracke, A., 2006. Trace element composition of mantle end-members:

8 Implications for recycling of oceanic and upper and lower continental crust. Geochem. Geophys. 7(4), Q04004, doi: 10.1029/2005GC001005.

903 Yang, Z.-F., Zhou, J.-H., 2013. Can we identify source lithology of basalt? Sci. Rep. 3, 1856, 904 doi: 10/1038/srep01856.

905 Zindler, A., Hart, S., 1986. Chemical geodynamics. Ann. Rev. Earth Planet. Sci. 14, 493-571, 906 doi: $10.1146 /$ annurev.ea.14.050186.002425. 


\section{FIGURE CAPTIONS}

Figure 1. Location of the Strait of Sicily, Italy-Tunisia. Rift valleys: PT, Pantelleria Trough; LT, Linosa Trough; MT, Malta Trough. Volcanic seamounts (Aissi et al., 2015): A, Anfitrite; AN, 911 Angelina; C, Cimotoe; CB, Pantelleria Central Bank; E, Pantelleria East; F, Foerstner; GB, 912 Graham Bank; G, Galatea; L1, Linosa I; L2, Linosa II; L3, Linosa III; NB, Nameless Bank; P, 913 Pinne; SE, Pantelleria Southeast; SW, Pantelleria Southwest. GoogleEarth v.7.3.2.5776 (13

914 December 2015). $36.7649^{\circ} \mathrm{N} 12.8443^{\circ} \mathrm{E}$, Eye alt $520 \mathrm{~km}$. SIO, NOAA, US Navy, GEBCO. 915 http://www.earth.google.com [20 November 2019] 928 (2008).

Figure 2. (a) Total-alkali versus silica (TAS) diagram for the classification of volcanic rocks (Le Maitre, 2002). (b) Basalt tetrahedron projected from clinopyroxene: $\mathrm{Q}^{\prime}=\mathrm{q}+0.4 \mathrm{ab}+0.25 \mathrm{hy}$; Ol' $=\mathrm{ol}+0.75 \mathrm{hy} ; \mathrm{Ne}{ }^{\prime}=\mathrm{ne}+0.6 \mathrm{ab}($ Irvine and Baragar, 1971). Alkali basalts plot below the plane of critical silica undersaturation (solid line); transitional basalts plot below the plane of critical silica saturation (dashed line). Units: PL, Paleo-Linosa; AB, Arena Bianca (Linosa); MB, Monte Bandiera (Linosa); PP, Paleo-Pantelleria; NP, Neo-Pantelleria; SEA, Semounts.

Figure 3. Major-element variation diagrams that use $\mathrm{MgO}$ as the differentiation index. Dashed lines illustrate the two major trends (see text for details.) Units: PL, Paleo-Linosa; AB, Arena Bianca (Linosa); MB, Monte Bandiera (Linosa); PP, Paleo-Pantelleria; NP, Neo-Pantelleria; SEA, Seamounts. Trends labeled A and B correspond to the Linosa trends of Di Bella et al. 
930 Figure 4. Trace-element variation diagrams that use $\mathrm{MgO}$ as the differentiation index. Units: PL, 931 Paleo-Linosa; AB, Arena Bianca (Linosa); MB, Monte Bandiera (Linosa); PP, Paleo-Pantelleria;

932 NP, Neo-Pantelleria; SEA, Seamounts Trends labeled A and B correspond to the Linosa trends 933 of Di Bella et al. (2008).

934

935 Figure 5. Representative rare-earth element diagrams (normalized to CI Chondrite; McDonough 936 and Sun, 1995). In each graph, $\mathrm{n}=$ the total number of analyses in the dataset. REE ratios are 937 reported either as a range or averages with standard deviation.

938

939 Figure 6. Pearce (1968) element ratios plotted with the results of MELTS (rhyolilte-MELTS 940 v.1.0.2; Gualda et al., 2012) models of fractional crystallization at 0.20 and $0.65 \mathrm{GPa}$. Vectors 941 show the slopes of the data distribution trends that would result from the fractionation of olivine $942(\mathrm{Ol})$, clinopyroxene $(\mathrm{Cpx})$, and plagioclase $(\mathrm{Pl})$

943

944 Figure 7. FractionatePT3 (Lee et al., 2009) model results for (a) anhydrous and (b) hydrous (1 $\left.945 \mathrm{wt}^{2} \mathrm{H}_{2} \mathrm{O}\right) \mathrm{LIN}-\mathrm{A}$ basalts with $10 \mathrm{wt} \%<\mathrm{MgO}<14 \mathrm{wt} \%$ calculated with $\mathrm{Fe}^{3+/} \Sigma \mathrm{Fe}=0.13$ and 946 mantle Fo $=90 \mathrm{~mol} \%$. Plotted with these are the P-T paths for isentropic melting of (a) 947 anhydrous and (b) hydrous $\left(116 \mathrm{ppm}_{2} \mathrm{O}\right)$ average depleted MORB mantle (DMM; Salters and 948 Stracke, 2004) calculated with pMELTS (v.5.6.1) at FMQ from the intersections of the $1415^{\circ}$ 949 and $1430^{\circ}$ adiabats with the (a) dry and (b) wet (116 ppm $\mathrm{H}_{2} \mathrm{O}$ ) lherzolite solidus (Katz et al., 950 2003). LAB: lithosphere-asthenosphere boundary. Gt-In, Sp-Out: garnet-spinel transition zone 951 (Klemme and O’Neill, 2000). Adiabats calculated following McKenzie and Bickle (1988) and 952 Putirka et al. (2007) (Supplementary Data 1). 
953

954 Figure 8. Trace element ratio diagrams, with REE ratios normalized to CI Chondrite

955 (McDonough and Sun, 1995). Dy/Dy* $=\mathrm{Dy}_{\mathrm{N}} /\left[\mathrm{La}_{\mathrm{N}}{ }^{4 / 13} \cdot \mathrm{Yb}_{\mathrm{N}}{ }^{9 / 13}\right]$ (Davidson et al., 2013). Units:

956 PL, Paleo-Linosa; AB, Arena Bianca (Linosa); MB, Monte Bandiera (Linosa); PP, Paleo-

957 Pantelleria; NP, Neo-Pantelleria; SEA, Seamounts. Identified geochemical groups are labelled, 958 as are the interpretations of the variation as discussed in the text.

959

960 Figure 9. Spiderdiagrams of representative samples (normalized to depleted MORB mantle

961 [DMM]; Salters and Stracke, 2004) for each of the geochemical groups identified in Figure 8.

962 Values in parenthesis are $\mathrm{wt} \% \mathrm{MgO}$ of each sample. The dotted lines superimposed on each

963 represent model non-modal fractional melts $(\mathrm{F}=0.02)$ of DMM for garnet peridotite $(\mathrm{GD})$ and

964 spinel peridotite (SD) (see Supplementary Data 2).

965

966 Figure 10. Results of rare-earth element inverse modelling (a, b, c), major- and trace-element

967 forward model predictions $(\mathrm{d}, \mathrm{e}, \mathrm{f})$, and calculated melting curves $(\mathrm{g}, \mathrm{h}, \mathrm{j})$ for LIN-A, LIN-B, and

968 PNL-L. Chondrite-normalized $\mathrm{Sm} / \mathrm{Yb}$ values represent the average of the sample set $(\mathrm{n}=$ total

969 number of samples used in the model). RMS = root mean square error. 


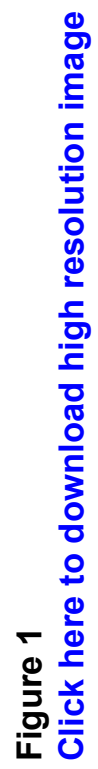

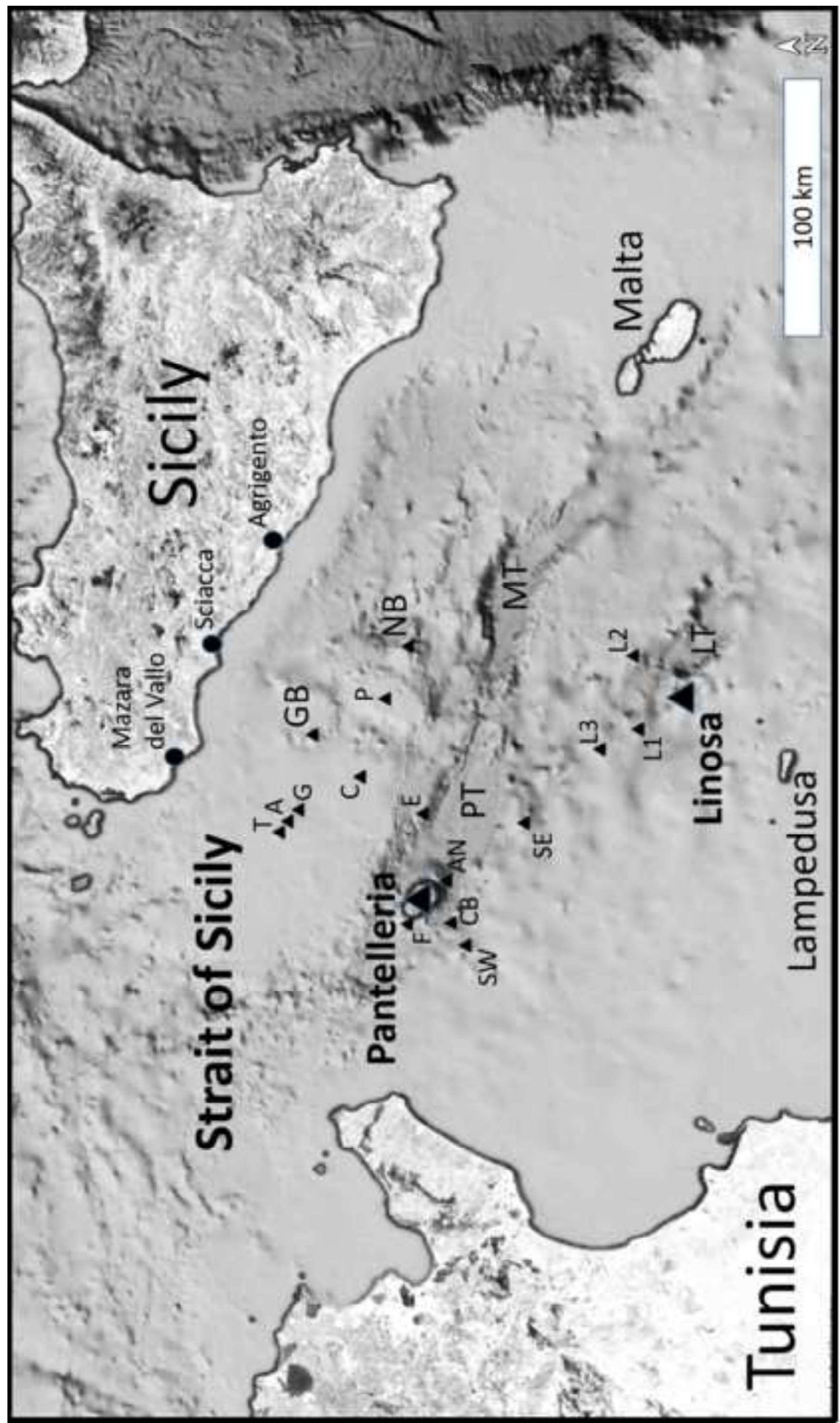



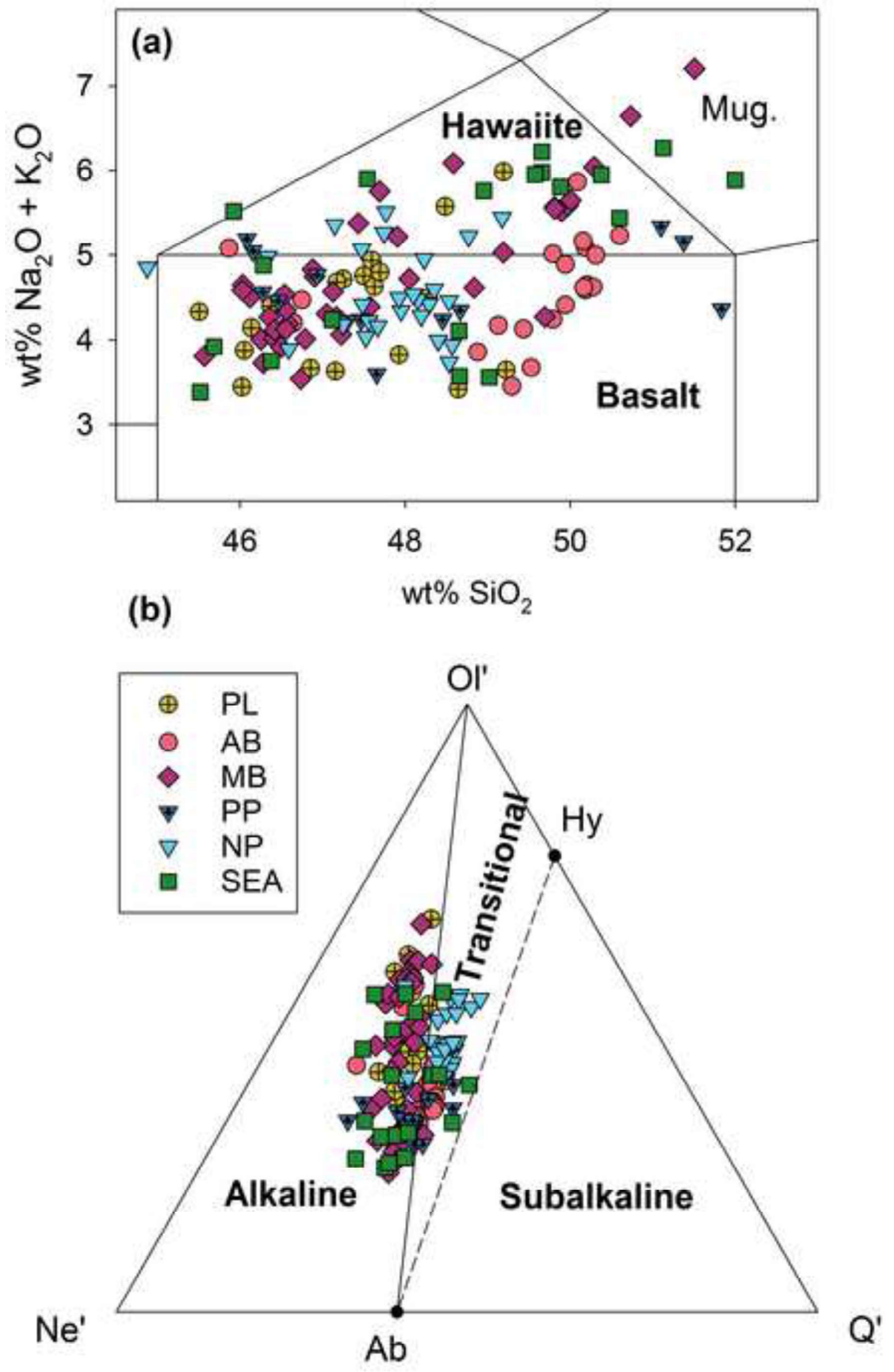
Figure 3

Click here to download high resolution image
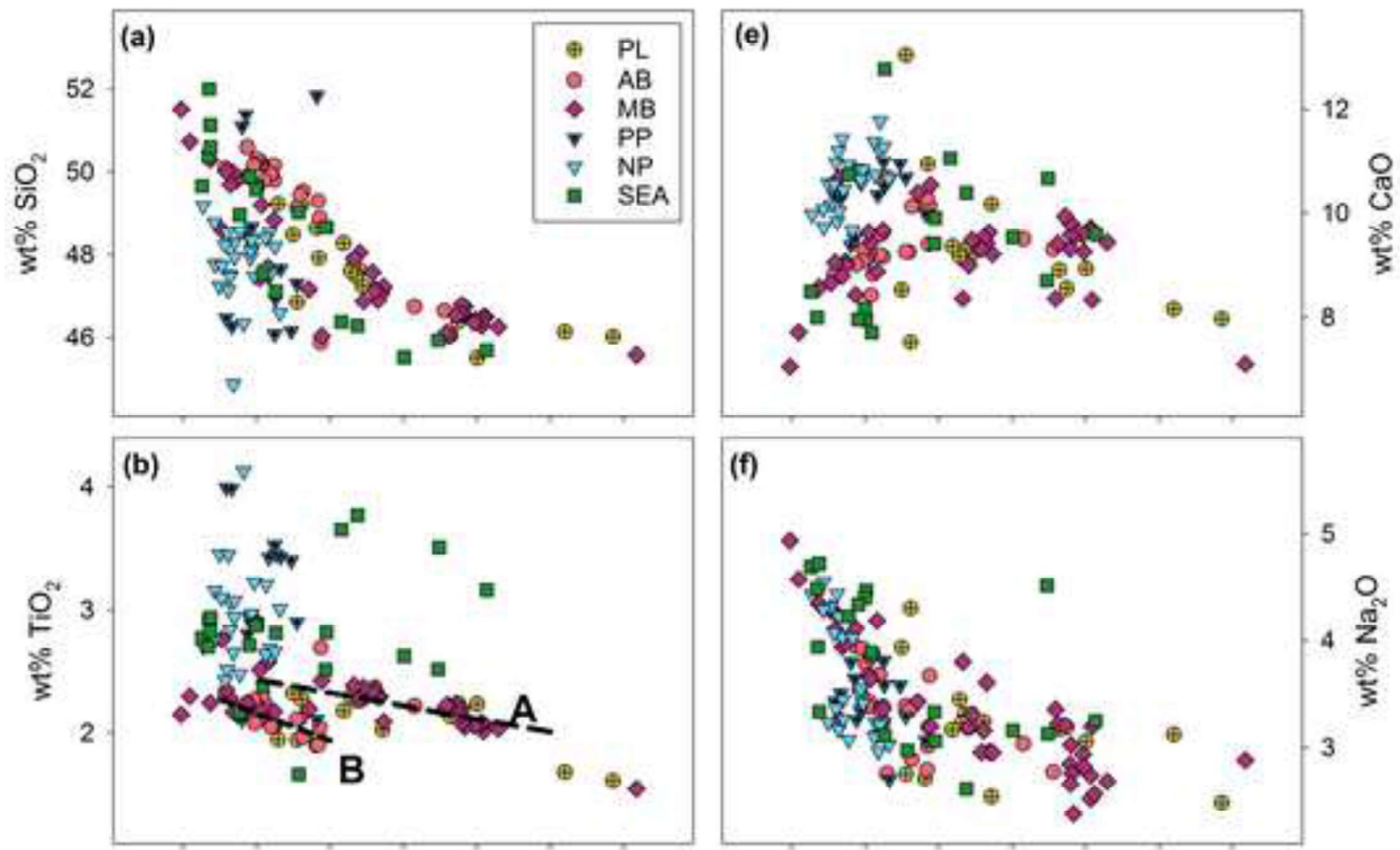

(f)
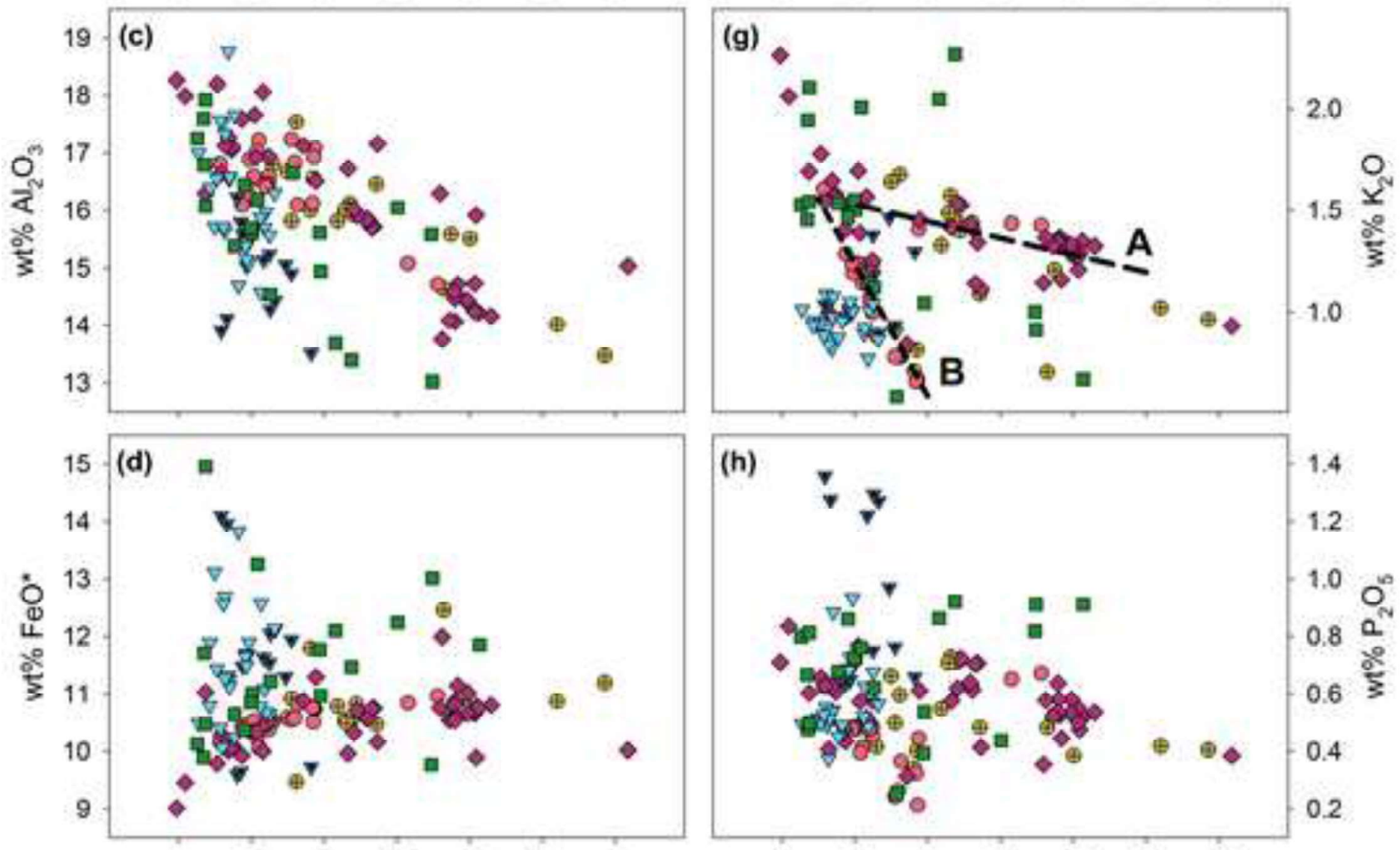

1.4

1.2

$1.0 \frac{0}{0}$
$0.8 \frac{2}{a^{\circ}}$
$0.6 \stackrel{\frac{2}{5}}{\frac{5}{3}}$

$\begin{array}{lllllll}4 & 6 & 8 & 10 & 12 & 14 & 16\end{array}$

$w t \% \mathrm{MgO}$ 

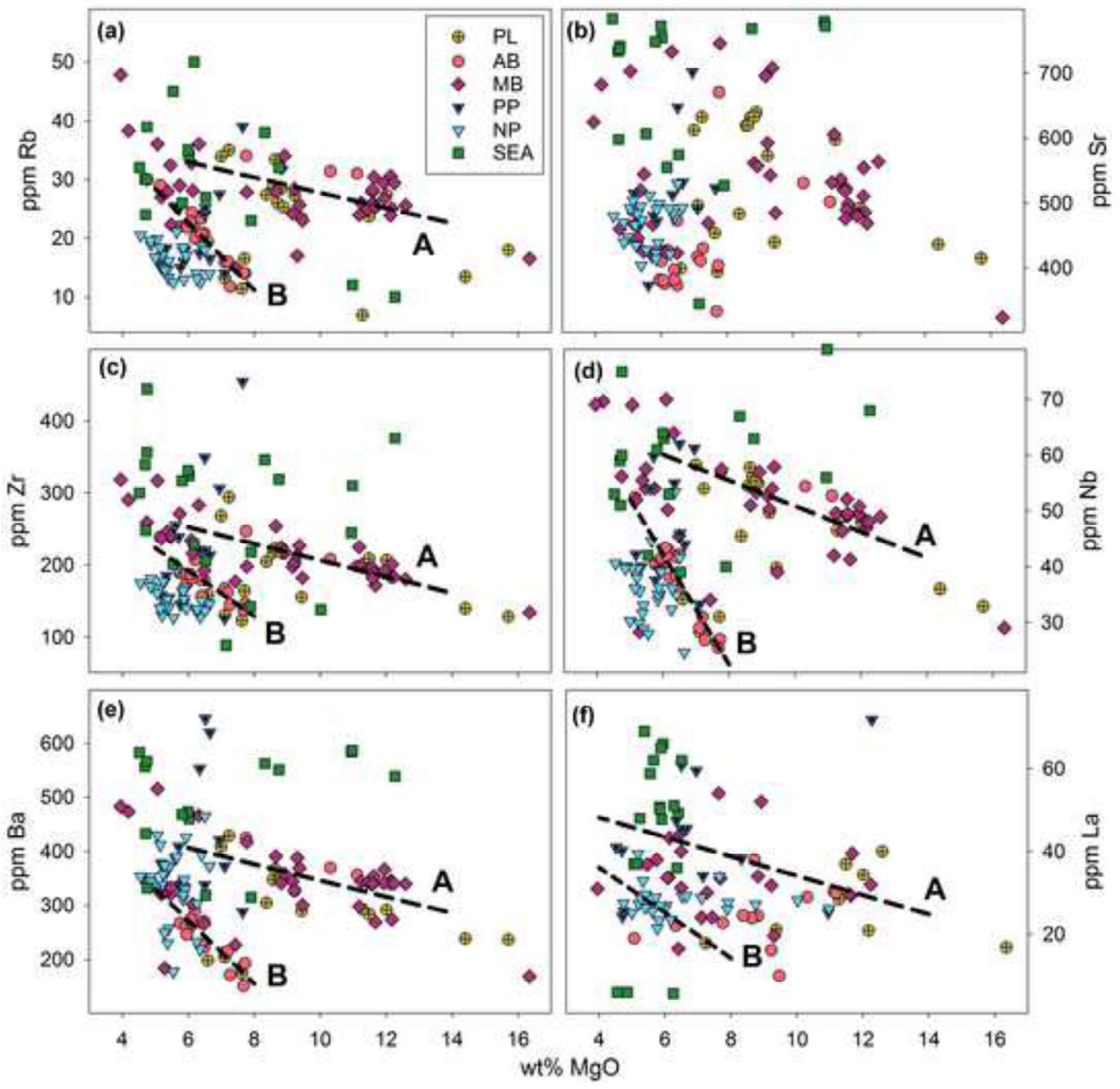


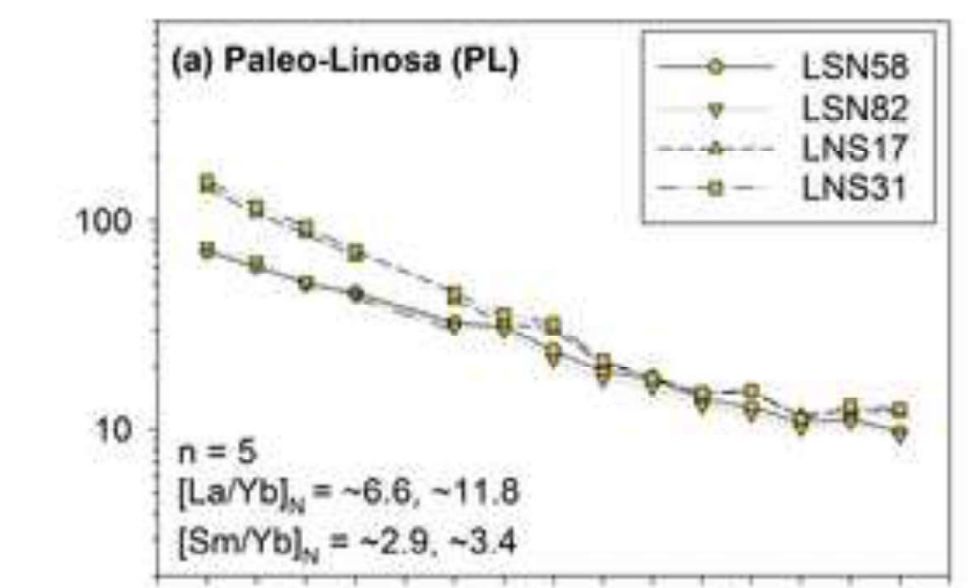

$n=13$
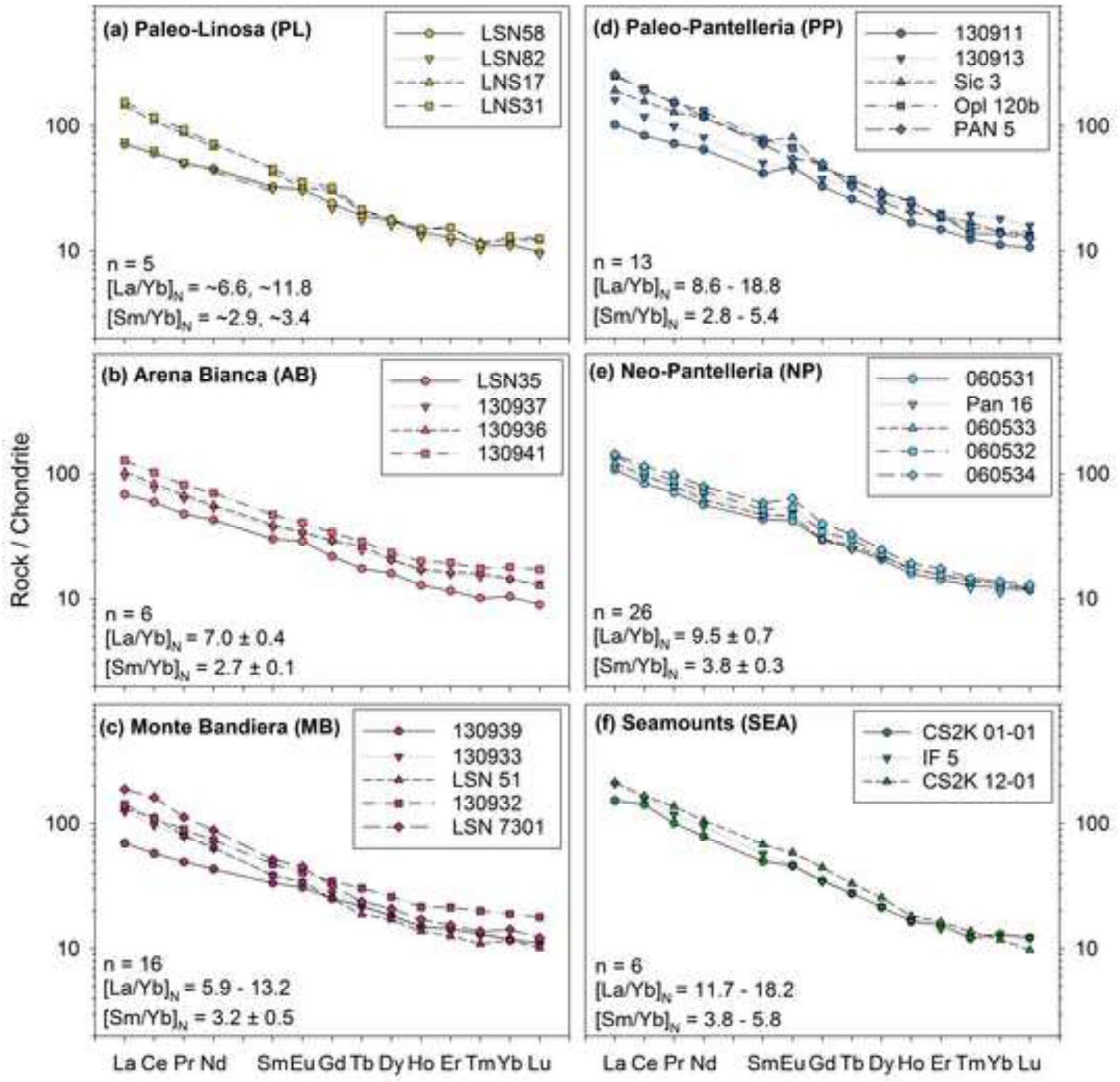

LaCe PrNd SmEuGdTbDyHo ErTmYbLu

La Ce PrNd SmEuGdTbDyHo ErTmYblu 

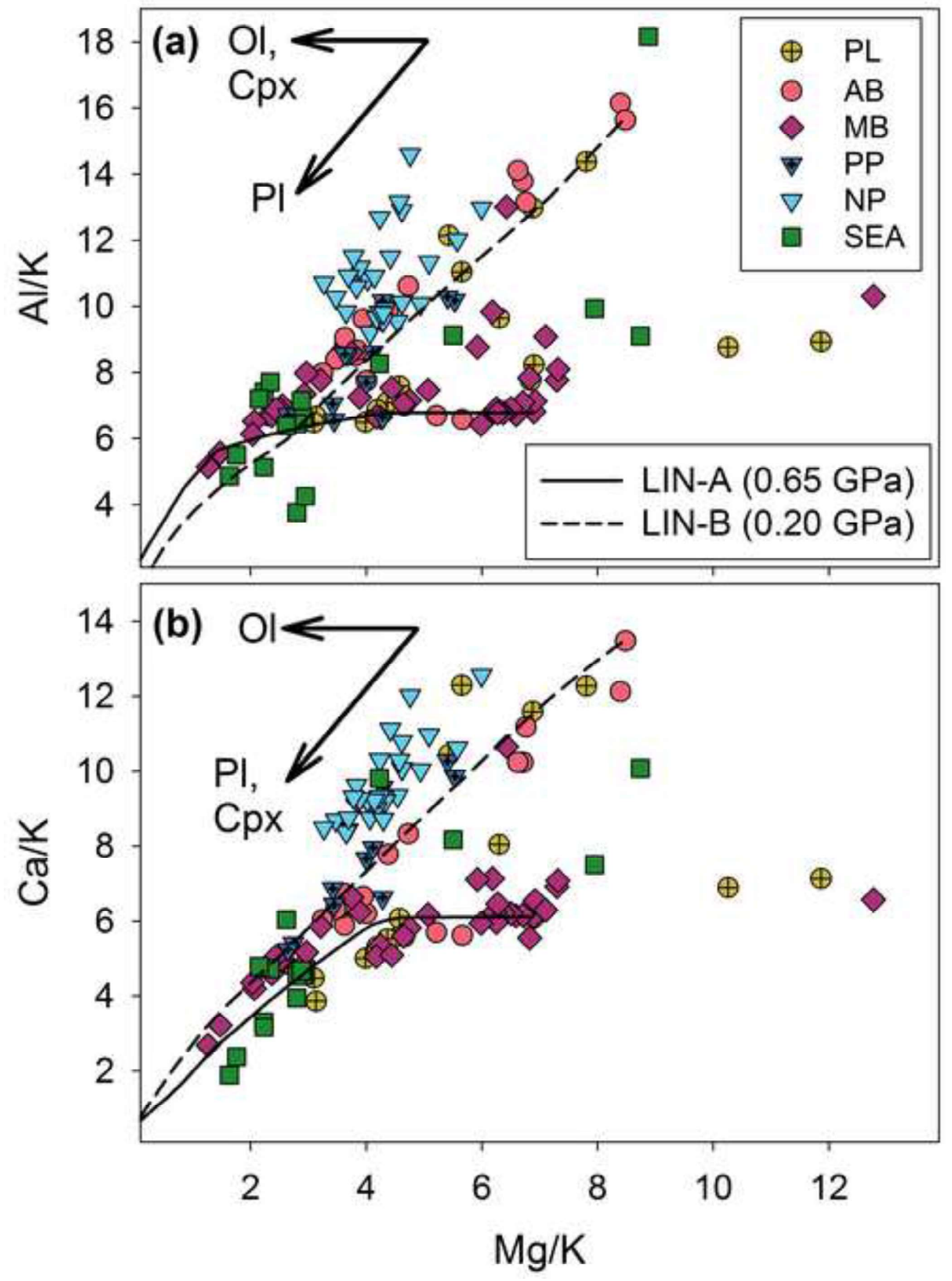


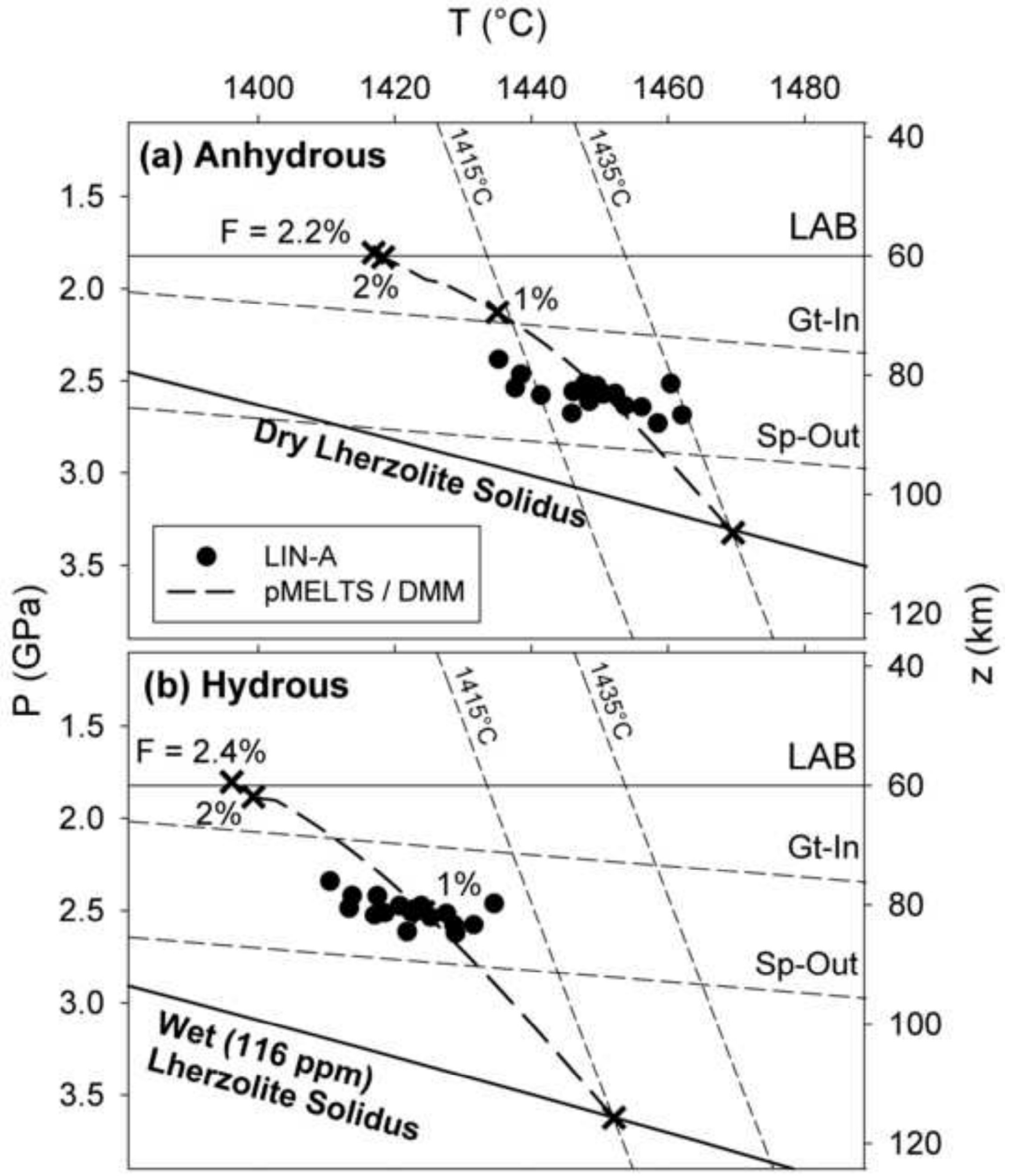



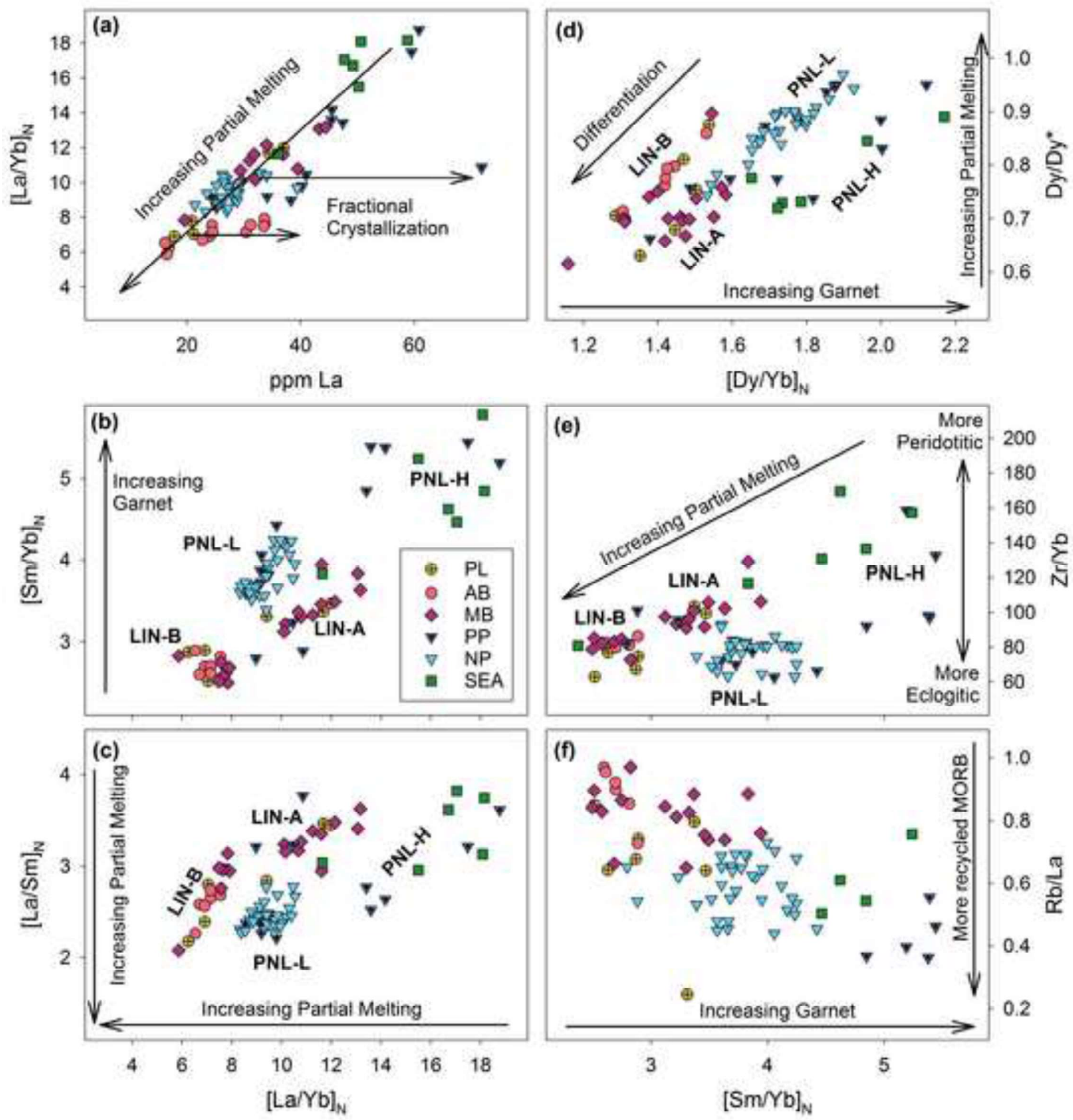
$\circ \div$
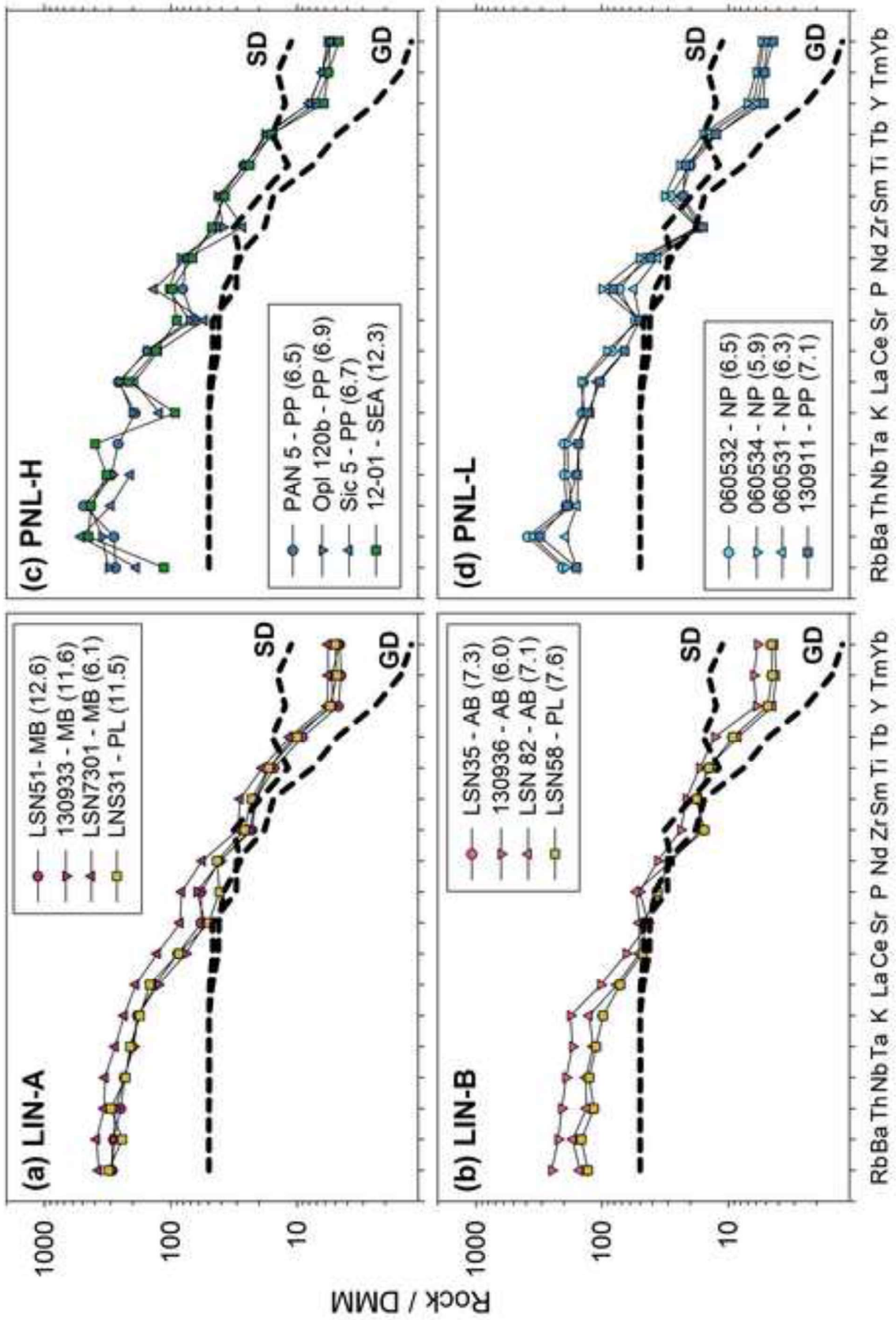
(ux) (z) usdeg

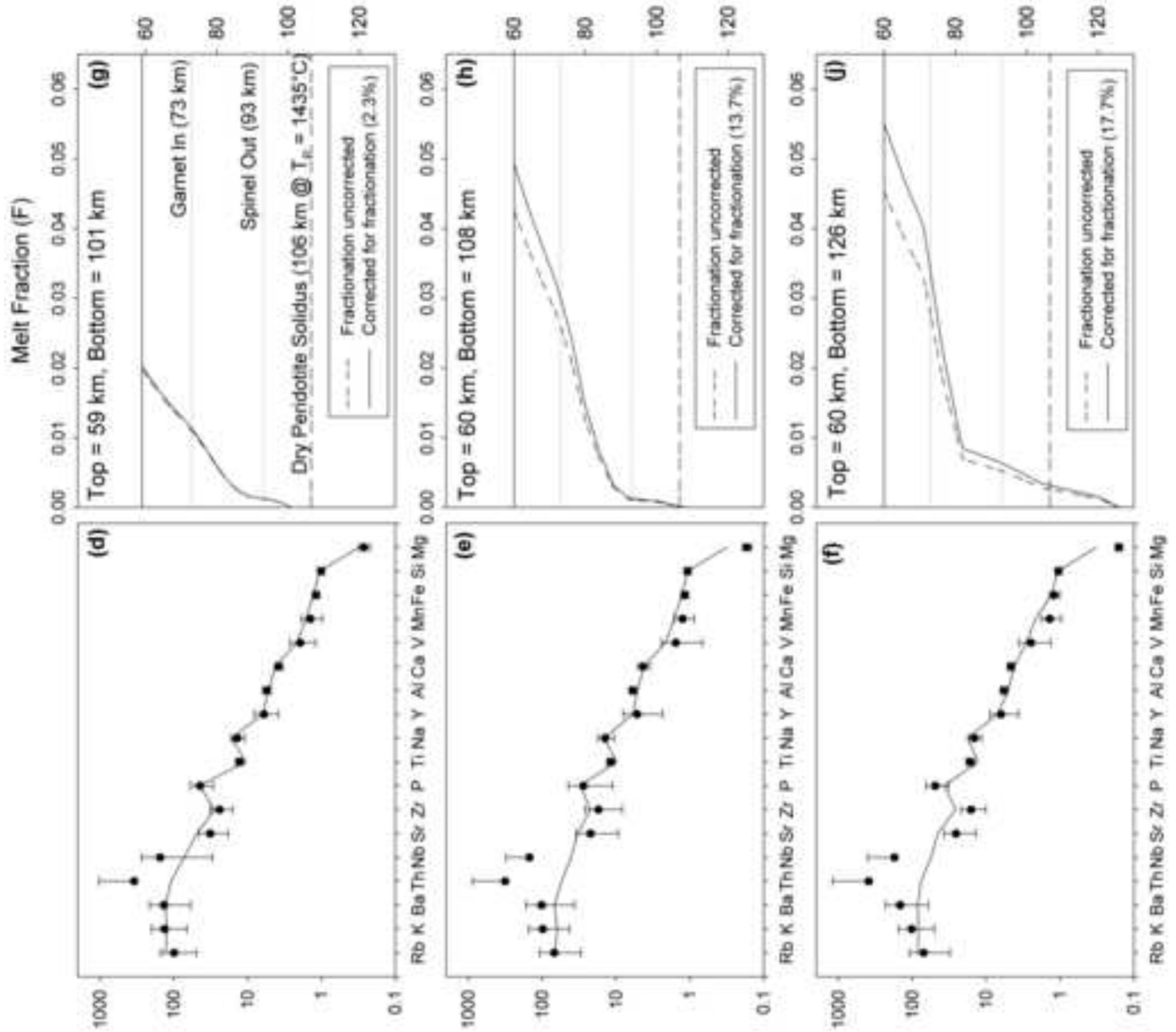

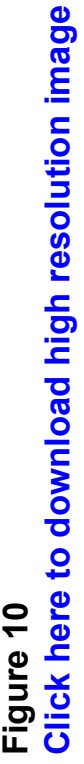
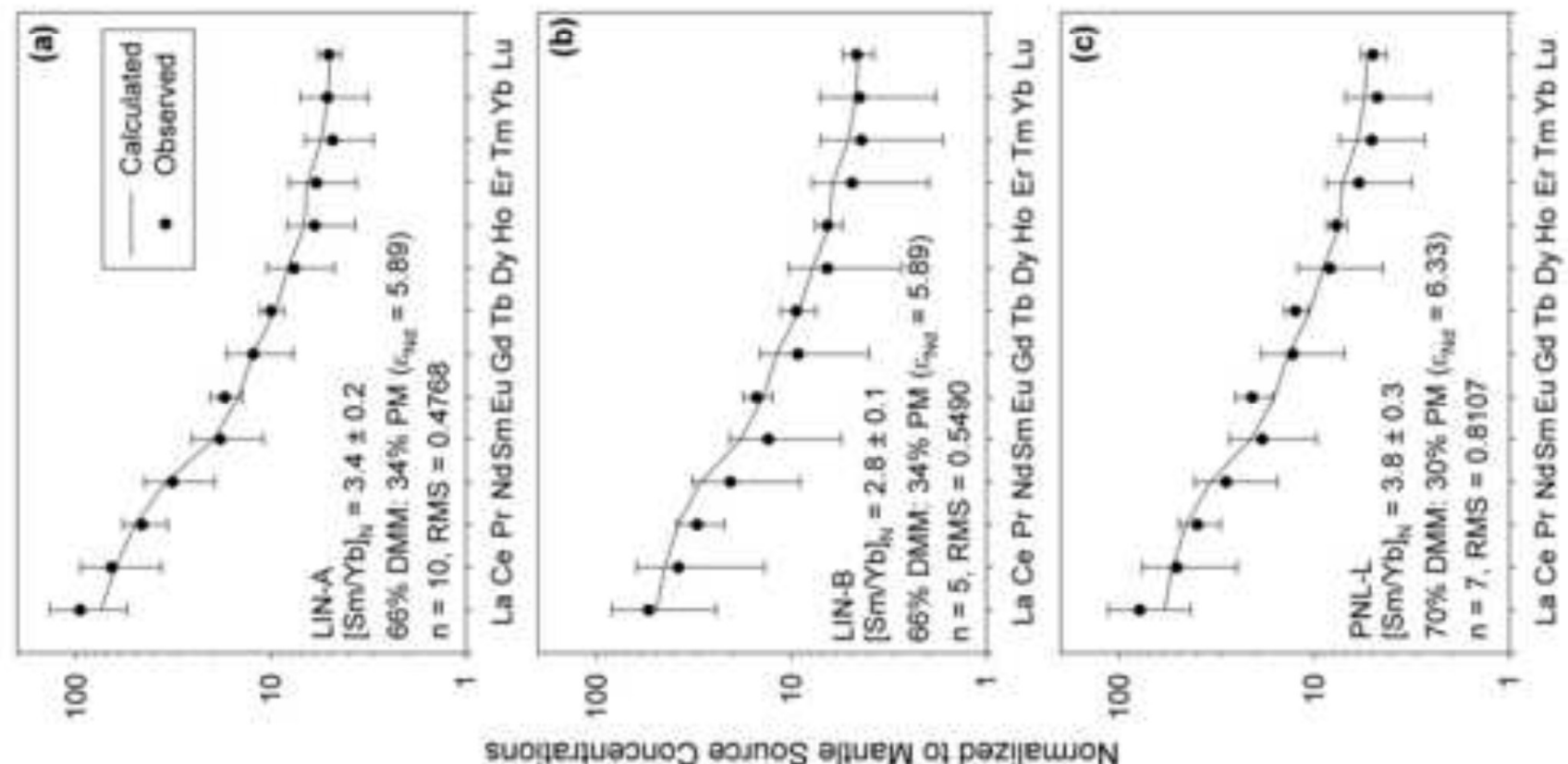
Table 1. Major and trace element compositions of volcanic rocks from Pantelleria and Linosa.

\begin{tabular}{|c|c|c|c|c|c|c|c|}
\hline Island: & Pantelleria & & & & & & \\
\hline Sample ID: & 130912 & 130911 & 060532 & 030512 & 060531 & 030508 & 130916 \\
\hline Phase: & PP & PP & NP & NP & NP & NP & PP \\
\hline Lat $(\mathrm{N})$ : & 36.8353 & 36.8107 & 36.8311 & 36.8366 & 36.8269 & 36.8197 & 36.8261 \\
\hline Long (E): & 11.9691 & 11.9286 & 11.9367 & 11.9477 & 11.9556 & 11.9286 & 11.9364 \\
\hline Class: & $\mathrm{tB}$ & $\mathrm{aB}$ & $a B$ & tB & $\mathrm{aB}$ & $A B$ & $\mathrm{aB}$ \\
\hline $\mathrm{SiO}_{2}, \mathrm{wt} \%$ & 50.36 & 47.14 & 47.72 & 47.83 & 48.23 & 46.52 & 48.69 \\
\hline $\mathrm{TiO}_{2}$ & 2.05 & 2.89 & 2.63 & 2.65 & 2.63 & 3.13 & 2.88 \\
\hline $\mathrm{Al}_{2} \mathrm{O}_{3}$ & 13.13 & 14.85 & 15.42 & 15.47 & 15.82 & 14.22 & 15.05 \\
\hline $\mathrm{Fe}_{2} \mathrm{O}_{3}^{\top}$ & 10.50 & 13.22 & 11.72 & 12.14 & 11.94 & 13.63 & 12.98 \\
\hline $\mathrm{MnO}$ & 0.17 & 0.19 & 0.17 & 0.16 & 0.16 & 0.18 & 0.19 \\
\hline $\mathrm{MgO}$ & 7.43 & 7.08 & 6.44 & 6.27 & 6.23 & 6.12 & 5.87 \\
\hline $\mathrm{CaO}$ & 9.69 & 10.65 & 11.17 & 11.08 & 11.33 & 10.48 & 10.69 \\
\hline $\mathrm{Na}_{2} \mathrm{O}$ & 2.98 & 3.28 & 3.21 & 2.92 & 3.09 & 3.16 & 3.35 \\
\hline $\mathrm{K}_{2} \mathrm{O}$ & 1.26 & 0.93 & 1.03 & 0.76 & 0.89 & 0.90 & 1.00 \\
\hline $\mathrm{P}_{2} \mathrm{O}_{5}$ & 0.64 & 0.76 & 0.67 & 0.48 & 0.52 & 0.61 & 0.65 \\
\hline LOI & 0.24 & -0.36 & 0.00 & 0.00 & 0.00 & 0.00 & -0.67 \\
\hline Total & 98.45 & 100.63 & 100.19 & 99.77 & 100.84 & 98.95 & 100.68 \\
\hline Mg\# & 60.89 & 54.09 & 54.73 & 53.19 & 53.44 & 49.69 & 49.87 \\
\hline Sc, ppm & 22 & 31 & 30 & 32 & 31 & 33 & 32 \\
\hline V & 176 & 307 & 274 & 280 & 295 & 323 & 320 \\
\hline $\mathrm{Cr}$ & 270 & 90 & 130 & 101 & 120 & 91 & 100 \\
\hline Co & 37 & 43 & 36 & 64 & 39 & 58 & 38 \\
\hline $\mathrm{Ni}$ & 170 & 80 & 65 & 57 & 60 & 57 & 50 \\
\hline $\mathrm{Cu}$ & 20 & 40 & 53 & n.a. & 78 & n.a. & 40 \\
\hline $\mathrm{Zn}$ & 130 & 90 & 75 & 94 & 76 & 103 & 100 \\
\hline $\mathrm{Ga}$ & 22 & 19 & 19 & 17 & 20 & 17 & 21 \\
\hline $\mathrm{Ge}$ & 1.8 & 1.7 & 1.1 & 1.6 & 1.1 & 1.6 & 2 \\
\hline $\mathrm{Rb}$ & 39 & 14 & 18 & 12 & 14 & 13 & 16 \\
\hline $\mathrm{Sr}$ & 523 & 492 & 530 & 485 & 492 & 421 & 472 \\
\hline$Y$ & 45.0 & 21.4 & 25.6 & 22.1 & 23.9 & 25.3 & 24.4 \\
\hline $\mathrm{Zr}$ & 454 & 126 & 137 & 128 & 136 & 139 & 147 \\
\hline $\mathrm{Nb}$ & 106.0 & 33.2 & 41.6 & 53.5 & 32.3 & 36.1 & 39.4 \\
\hline $\mathrm{Ba}$ & 288 & 373 & 465 & 219 & 233 & 304 & 335 \\
\hline La & 71.80 & 24.3 & 32.9 & 26.0 & 25.5 & 28.80 & 25.6 \\
\hline $\mathrm{Ce}$ & 136.00 & 51.3 & 64.3 & 49.6 & 51.3 & 56.77 & 54.5 \\
\hline $\operatorname{Pr}$ & 15.80 & 6.67 & 8.24 & 6.12 & 6.56 & 6.98 & 6.97 \\
\hline $\mathrm{Nd}$ & 59.20 & 29.5 & 32.9 & 27.4 & 25.8 & 31.04 & 30.4 \\
\hline $\mathrm{Sm}$ & 11.90 & 6.17 & 7.7 & 6.35 & 6.37 & 7.37 & 6.76 \\
\hline $\mathrm{Eu}$ & 2.75 & 2.65 & 3.02 & 2.30 & 2.37 & 2.74 & 2.65 \\
\hline $\mathrm{Gd}$ & 10.80 & 6.54 & 6.87 & 6.39 & 5.89 & 7.32 & 6.59 \\
\hline $\mathrm{Tb}$ & 1.72 & 0.94 & 1.08 & 1.02 & 0.92 & 1.12 & 1.01 \\
\hline Dy & 9.46 & 5.17 & 5.61 & 5.24 & 5.07 & 5.91 & 5.38 \\
\hline
\end{tabular}

